University of Nebraska - Lincoln

DigitalCommons@University of Nebraska - Lincoln

Common birds of Southeastern United States in Relation to Agriculture

\author{
F. E. L. Beal \\ Fish and Wildlife Service \\ W. L. McAtee \\ Fish and Wildlife Service \\ E. R. Kalmbach \\ Fish and Wildlife Service
}

Follow this and additional works at: https://digitalcommons.unl.edu/usfwspubs

Part of the Aquaculture and Fisheries Commons

Beal, F. E. L.; McAtee, W. L.; and Kalmbach, E. R., "Common birds of Southeastern United States in Relation to Agriculture" (1941). US Fish \& Wildlife Publications. 246.

https://digitalcommons.unl.edu/usfwspubs/246

This Article is brought to you for free and open access by the US Fish \& Wildlife Service at DigitalCommons@University of Nebraska - Lincoln. It has been accepted for inclusion in US Fish \& Wildlife Publications by an authorized administrator of DigitalCommons@University of Nebraska - Lincoln. 


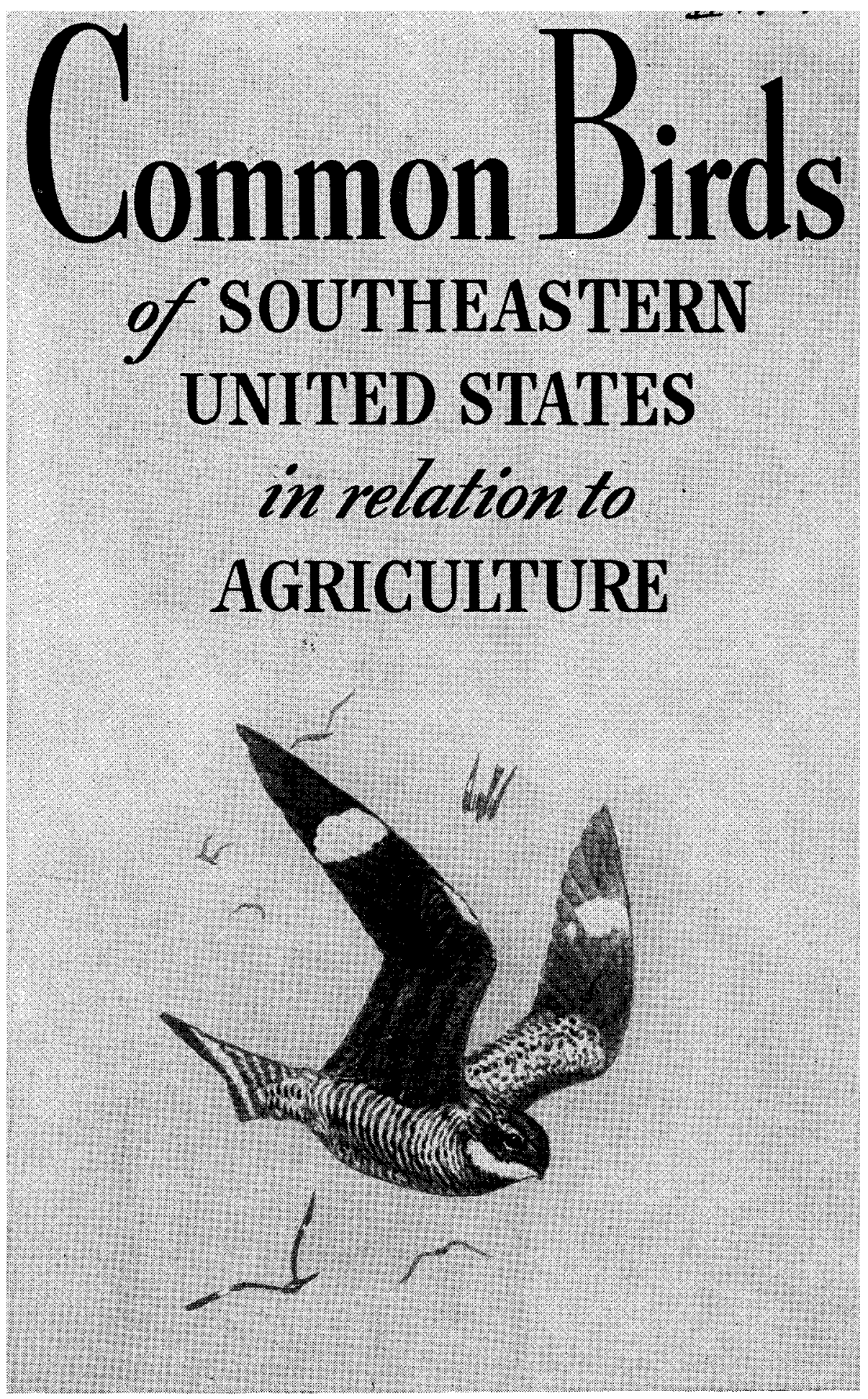

U. S. DEPARTMENT of the INTERIOR Fish and Wildlife Service Conservation Bulletin 15 
UNITED STATES DEPARTMENT OF THE INTERIOR

Harold L. Ickes, Secretary

FISH AND WILDLIFE SERVICE

Ira N. Gabrielson, Director

Conservation Bulletin 15

\title{
COMMON BIRDS OF SOUTHEASTERN UNITED STATES IN RELATION TO AGRICULTURE
}

\author{
BY \\ F. E. L. BEAL \\ Former Biologist \\ W. L. McATEE \\ Technical Adviser, Office of the Director \\ AND \\ E. R. KALMBACH \\ Biologist, Section of Food $\mathbf{H a b i t s}$ \\ Division of Wildlife Research \\ Fish and Wildlife Service
}

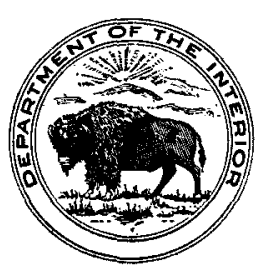

UNITED STATES

GOVERNMENT PRINTING OFFICE

WASHINGTON : 1941

For sale by the Superintendent of Documents, Washington, D. C. . . . . . Price 10 cents 
$\mathrm{H}^{\mathrm{ROM}}$ a purely practical point of view the most important of the relations of native birds to man are the economic. The esthetic value of birds is great, greater indeed than that of any other group of animals; and that this is a real and especially a treasured value is not to be denied. But it is in their relation to insect and other enemies of crops that birds are most directly associated with the welfare of mankind, and their value in this particular should be made as widely known as possible. This bulletin is one of a series designed to assist in doing this. Not all birds are beneficial, and all facts tending to show in which class each species belongs will be set forth. The useful kinds far outnumber the injurious, however, and so great is their value as insect destroyers in the United States that to them may be given the credit of being one of the greatest controlling factors in limiting the development of insect pests and in preventing many disastrous outbreaks. In the following pages are discussed the food habits and relation to agriculture of 23 species of birds common in the Southeastern States. The bulletin will be of general interest, but is especially applicable to the section shown by the shaded portion of the map on page 1 . 


\section{COMMON BIRDS OF SOUTHEASTERN UNITED STATES IN RELATION TO AGRICULTURE}

\begin{tabular}{|c|c|c|c|}
\hline \multicolumn{4}{|c|}{ CONTENTS } \\
\hline & Page & & Page \\
\hline Louse wren .... & 6 & Carolina chickadee. ... & \\
\hline Carolina wreu... & 8 & Tufted titmouse..................... & \\
\hline Mocking bird & 10 & Purple martin & \\
\hline Brown thrasher & 12 & Scissor-tailed flycatcher & \\
\hline Cardinal & 14 & Red-cockaded woodpecker & \\
\hline Gray grosbeak & 15 & Chuck-will's-widow & \\
\hline Painted bunting & 17 & Nighthawk & \\
\hline Common crow & 18 & Yellow-billed cuckoo & \\
\hline Blue jay & 20 & Bobwhite & \\
\hline Meadow lark & 21 & Barn owl & \\
\hline Boat-tailed grackle & 24 & Turkey buzzard & \\
\hline Bluebird & 25 & & \\
\hline
\end{tabular}

TN THE Southeastern States, as restricted for the purposes of this 1 bulletin (fig. 1), there occur at some season of the year more than 460 species of birds. Of these, about 280 are common, and the number includes some of the handsomest birds of the United States, as the scissor-tailed flycatcher, the painted bunting, and the cardinal; besides some of the most pleasing songsters, as the last-named species, the mocking bird, the brown thrasher, and the

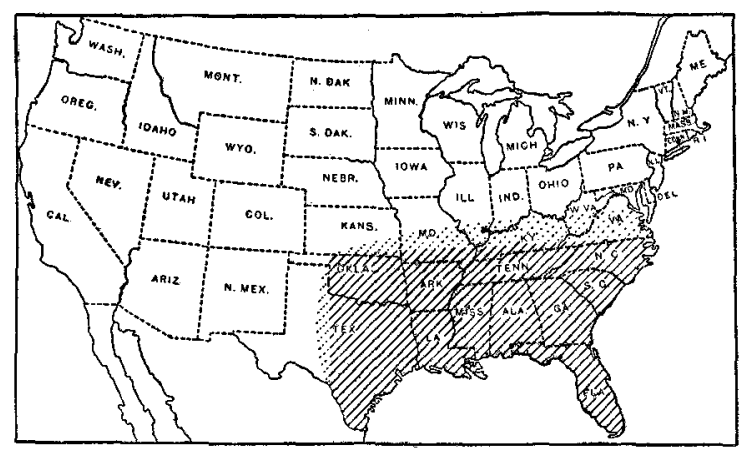

FiG. 1.-Map of the United States, the shaded area showing the territory to which this bulletin applies Carolina wren. The

general habits, and particularly the economic value, of 23 of the bestknown species are treated in the following pages.

The food habits of southeastern birds are of particular interest on account of the prevalence in this section of the country of a number of the worst insect enemies of agriculture, many of which are eagerly sought by birds. One need only recall such pests as the cotton boll weevil, the bollworm, and the chinch bug to realize with what serious

NoтE.-This bulletin supersedes, with minor revisions, Farmers' Bulletin 755, issued in 1916 by the U. S. Department of Agriculture-a contribution of the Bureau of Biological Survey, which was consolidated in 1940 with the Bureau of Fisheries to form the Fish and Wildlife Service, U. S. Department of the Interior. 
foes the farmer of the Southeastern. States has to contend. It is hoped that knowledge of the part birds play in combating his enemies will lead the southern farmer to take an active interest in securing full protection for these, his feathered allies.

Cotton being the leading crop in the Southeast, the bird enemies of cotton insect pests naturally deserve first consideration. Few in all this broad land are ignorant of the tremendous damage done by the cotton boll weevil. For some years it has easily ranked as the most destructive pest in the United States. Special study of its bird enemies has been made, and the result is that 66 species are now known which, to a greater or less extent, prey upon the boll weevil. A list of these, which constitutes a roll of honor among southeastern birds, is here given:

Bird Enemies of the Cotton Boll Weevil

Upland plover.

Killdeer.

Bobwhite.

Red-headed woodpecker.

Flicker.

Nighthawk.

Chimney swift.

Scissor-tailed flycatcher.

Kingbird.

Crested flycatcher.

Phobe.

Olive-sided flycatcher.

Wood pewee.

Alder flycatcher.

Least flycatcher.

Blue jay.

Cowbird.

Red-winged blackbird.

Meadow lark.

Western meadow lark.

Orchard oriole. (Fig. 2.)

Baltimore oriole.
Bullock oriole. Rusty blackbird. Brewer blackbird.

Bronzed grackle.

Boat-tailed grackle.

English sparrow.

Vesper sparrow.

Savannah sparrow.

Lark sparrow.

White-throated sparrow.

Field sparrow.

Chipping sparrow.

Swamp sparrow.

Fox sparrow.

Towhee.

Cardinal.

Gray grosbeak.

Blue grosbeak.

Painted bunting.

Indigo bunting.

Dickcissel.

Purple martin.

\author{
Cliff swallow. \\ Barn swallow. \\ Tree swallow. \\ Bank swallow. \\ Rough-winged swallow. \\ Loggerhead shrike. \\ White-eyed vireo. \\ Yellow warbler. \\ Myrtle warbler. \\ Pine warbler. \\ Maryland yellow-throat. \\ Yellow-breasted chat. \\ American pipit. \\ Mocking bird. \\ Brown thrasher. \\ Carolina wren. \\ Bewick wren. \\ Winter wren. \\ Tufted titmouse. \\ Black-crested titmouse. \\ Carolina chickadee. \\ Bluebird.
}

The most active of these enemies of the boll weevil are the orioles, which actually take the insects from the squares of the cotton plant, and the swallows, which feed upon the weevils when they are in flight and seeking to extend their range. No fewer than 41 boll weevils have been found in a single stomach of the Bullock oriole, and large numbers of the weevils are habitually taken by all species of swallows. Every one of a series of 35 cliff swallows had eaten boll weevils, the largest number in any stomach being 48 , and the average 19 . In winter the most important destroyers of these insects are blackbirds, meadow larks, pipits, and Carolina wrens. 


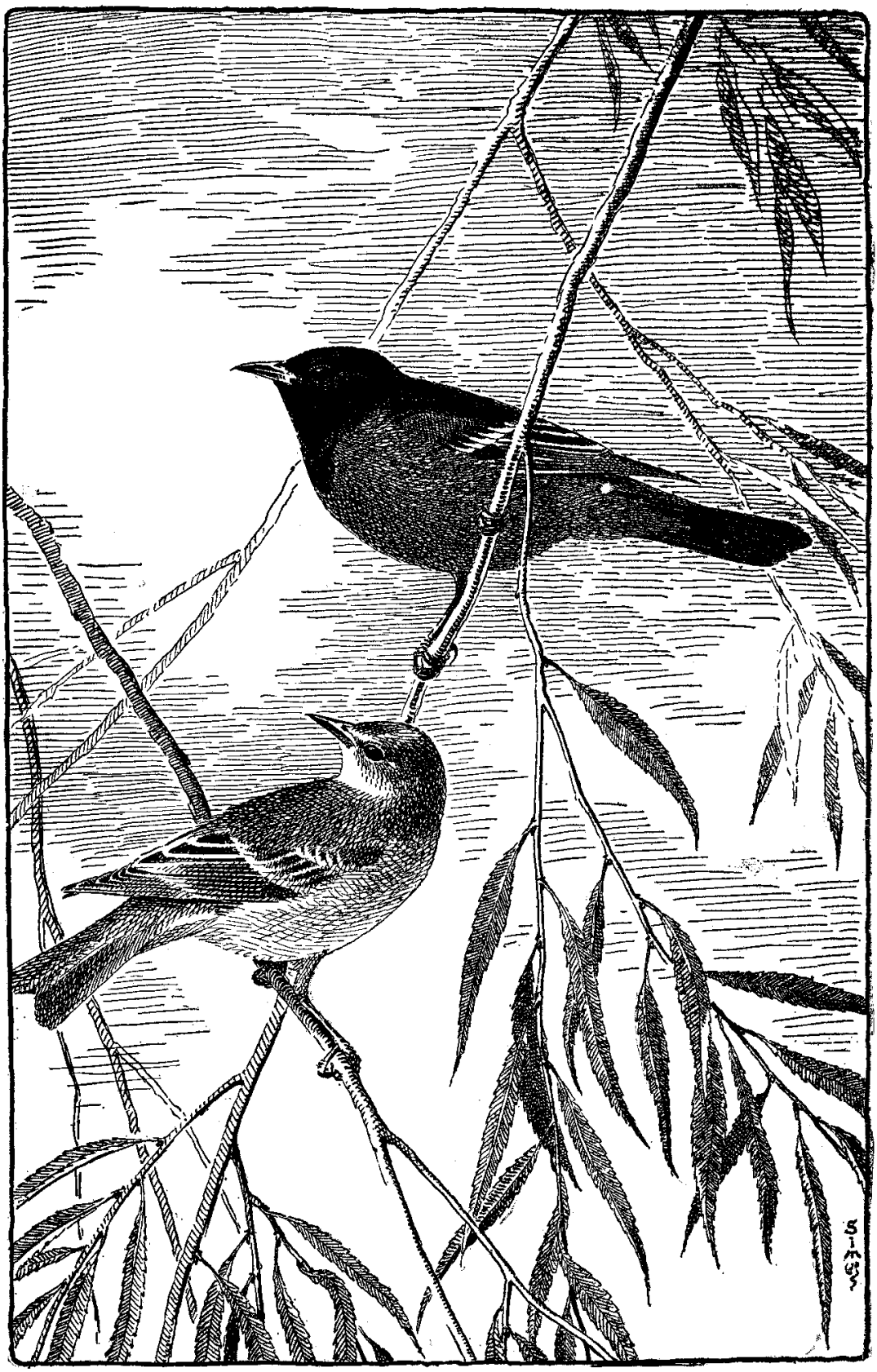

Fra. 2.-Orchard oriole (Icterus spurius); upper figure, malo; lower, female. Length, about 71/2 inches. Three kinds of orioles are prominent among bird enemies of the boll wervil. Of these the orchard oriole is most common in the Southeastern States. The food habits of orioles in general are commendable 
Forty-one species ${ }^{1}$ of birds feed upon the cotton worm. Of these bird enemies, cuckoos are most effective, since they frequently consume from 100 to 150 cotton worms at a meal. The orioles again deserve especial mention, as do also the crow, the curve-billed thrasher, mocking bird, cardinal, and gray grosbeak. The bollworm, or corn-ear worm, is attacked by 12 southeastern birds, of which the boat-tailed grackle, or jackdaw, has the best record. Seven species of birds feed upon the cotton cutworm.

If insect pests are considered in the order of the importance of the crops they attack, those damaging corn and other grain crops probably are next to the cotton insects. White grubs are a serious pest not only to corn but to strawberries, various garden crops, and grasses. Fifty-seven species of southeastern birds devour white grubs or the alult forms known as May beetles. The nighthawk, chuck-will'swidow, crow, and screech owl are the most voracious feeders on the arlults, and the crow, grackles, and robin on the larvæ. Remains of no fewer than 91 adults have been found in a single stomach of the nighthawk, or bull bat, a bird which has been much persecuted but which deserves the strictest protection.

Wireworms are especially injurious to corn, but they damage all other grains, as well as many garden crops. These pests are the larvæ of click beetles, of which there are many species. One hundred and twenty-eight southeastern birds include click beetles or wireworms in their bill of fare. The most efficient destroyers of these pests are the following: Downy and red-bellied woodpeckers, nighthawk, kingbird, great-crested flycatcher, crow, blue jay, grackle, red-winged blackbird, lark sparrow, tree swallow, purple martin, house wren, and robin. From 20 to 40 wireworms have been found in each of several robin stomachs.

Corn is seriously damaged by billbugs also. The larvæ bore into the stem and the adult weevils injure the leaves. Fifty-five species of birds occurring in the Southeastern States feed upon these insects. Those consuming the largest numbers are the killdeer, upland plover, nighthawk, crow, red-headed woodpecker, and the yellow-headed blackbird and grackle. Forty-three kinds of birds feed upon the army worms, pests destructive to corn and all small grains. Eightyeight southeastern species devour cutworms, which are often the despair of grain growers and gardeners. Largest numbers of cutworms have been found in stomachs of the prairie chicken, bobwhite, wood duck, woodcock, sparrow hawk, yellow-billed cuckoo, nighthawk, red-headed woodpecker, grackle, meadow lark, English sparrow, cardinal, and robin.

\footnotetext{
1 This and similar figures must be understood as representing only present knowledge-other species may at any time be added to the lists of bird enemies of the various insect pests.
} 
No insect enemy of corn and wheat is more destructive than the chinch bug; when it is numerous, fields are blasted as if by fire. It is often said that the chinch bug has few natural enemies, but the work of birds, 24 species of which feed upon chinch bugs, should not be overlooked. Over 100 of these pests have been found in single stomachs of the bobwhite and meadow lark, and over 200 in one of a brown thrasher. Other birds consuming chinch bugs in considerable numbers are the flicker, the crow, the barn, tree, and cliff swallows, and the house wren. The southern corn-leaf beetle, a pest that has come to be of considerable importance in the past few years, is devoured by 22 kinds of birds. Those taking the largest numbers are the mocking bird, the Bewick wren, and the house wren.

Among other corn insects may be mentioned the southern corn rootworm (or spotted cucumber beetle), eaten by 26 species of southeastern birds; beetles of a group including the cane root borer and the carrot beetle, devoured by 18 species; and the brown fruit chafer, by 21 . The last-named beetle feeds also on apples, pears, and peaches, as does a related insect known as the southern fig eater. Fourteen species of birds prey upon the fig eater, the crow most extensively.

The insect pests of clover and other forage crops in the Southeastern States also are sought by many birds. Perhaps more damage is done in the aggregate by leafhoppers than by other enemies of these crops. Exactly 100 species of southeastern birds are now known to feed on these small but exceedingly numerous insect pests. Largest numbers of leafhoppers have been found in stomachs of the nighthawk, chimney swift, barn swallow, and yellow-headed blackbird. Clover is attacked by a number of insect pests, including the imbricated-snout beetle and the various clover weevils. The first named is eaten by 20 kinds of birds, of which the crow, grackle, and catbird seem most voracious. The common or large clover-leaf weevil is the prey of 25 species of birds. The nighthawk, crow, red-headed woodpecker, purple martin, and grackle have the best records for destruction of adults, and the Savannah and vesper sparrows of the larvæ. The smaller clover weevils are eaten by 74 species of southeastern birds. Largest numbers of these weevils have been found in the stomachs of the robin, hermit thrush, tufted titmouse, and white-crowned sparrow, and of the following four species of birds, some representative of each of which had consumed at one meal more than 50 individuals: Nighthawk, chimney swift, tree swallow, and purple martin.

It is perhaps worth while to mention the bird predators upon certain insect enemies of truck crops. The destructive little cucumber flea beetle and its congeners, which feed on potato, tomato, sweet potato, eggplant, and tobacco, are preyed upon by 19 species of $414228^{\circ}-41-2$ 
southeastern birds. The sweet potato flea beetle and its allies have 28 known bird enemies in this section; the grapevine leaf beetle, 21; the grape flea beetle, 23; and the bean leaf beetle, 19. The rice weevil has been found in stomachs of 20 species of birds, the notorious Colorado potato beetle in 26 , and the periodical cicada, or 17-year locust, in 33. Pests of considerable importance in the South whose bird enemies it is well to mention are the horseflies. These are preyed upon by 49 species of southeastern birds. The stomach of one killdeer contained 40 horsefly larvæ.

The foregoing demonstrates that many of the worst pests of southern agriculture have enemies in the bird world. The insects that have been considered chiefly are those destructive to grain and field crops; but among forest insects, fruit insects, and all the host that prey upon truck and garden crops, few can be mentioned that do not have important bird enemies. Farmers should recognize their friends and do all in their power to protect them.-W. L. M.

\section{HOUSE WREN 1}

The house wren (fig. 3), a fussy, flighty, and fidgety little midget, frequents the vicinity of barns and gardens and particularly old orehards where the trees are partially decayed. Never for a moment at rest while there is a ray of daylight, it would seem that his small body must soon be worn out by his incessant activity. His voice, as tireless as his wings, is heard from morning until night about the garden and orchard where he seeks his daily food, and while not very melodious it is cheerful and suggestive of life and activity.

Probably no bird displays greater eccentricity in the selection of a nesting site than the house wren. A hollow branch or a knothole in a post or stump is his more prosaic choice. When more esthetically inclined he affects old boots or hats hung up to scare the robin from the cherries, or takes an old copper pot or tomato can lying on the roof of a back shed; or, if the gardener hangs his coat on the fence when warm weather begins and forgets it for a few days, he may find when he returns that an enterprising wren has proempted one of the pockets and has his domestic affairs under full headway. The empty skull of a horse or cow when set on a post by the frolicsome schoolboy makes an excellent nesting place for the wren, who is never troubled by the ghost of the former occupant. Whatever place he chooses, his ambition is to occupy the whole of it. This he accomplishes by carrying in sticks, straws, and other rubbish until all available space is filled, only just room enough being left for the mother bird and her eggs.

Curious as may be the nesting habits of this little creature, his chief interest to the farmer and gardener centers about his tastes in the matter of food. He aspires to a large family; six to a brood is his favorite number, and this he likes to duplicate once or twice in the course of the summer; of course, so many mouths to be filled require great activity on the part of the head of the family, but the wren is fully equal to the task and his brood never suffers from hunger. He is an industrious forager, searching every tree, shrub, and vine for caterpillars and examining every past and rail of the fence and every cranny in the wall for inects and spiders.

The wren is found all over the United States east of the Great Plains in summer and it winters in the Southern States.

Troglodytes aëdon. 
For the purpose of this paper the food of 68 birds was examined and found to consist entirely of animal matter (mostly insects). The largest four items taken in the order of their size, are bugs, grasshoppers and their allies, caterpillars, and beetles. Beetles collectively constitute 13.81 per cent of the food. Of these, the predacious ground beetles and a number of "Iadybugs" ( 3.03 per cent) are practically the only useful insects eaten by the wren. Snout beetles, or weevils (4.93 per cent), are eaten in every month of the wren's stay in the South. Other beetles ( 5.85 per cent) are largely of the leaf-beetle family, to which belong some. of the greatest pests in the insect world.

Moths and caterpillars reach very nearly the same percentage as beetles. The former are eaten to the extent of 13.9 per cent, but many are adult insects instead of caterpillars. The wren seems to have a decided taste for these fuzzy creatures.

Grasshoppers and their kin-crickets, locusts, etc.-were represented in the food of every month in goodly numbers, the aggregate being 17.61 per cent. The greatest consumption occurred in January (31.2 per cent) and November (31 per cent); the smallest, a mere trifle, in April. The largest item in the food is made up of bugs $(29.34$ per cent), chiefly stinkbugs, a few negro bugs, and some leafhoppers; but a good many more are those slim-bodied, longlegged, slow-moving creatures that may be found straddling over the herbage about pools or wet places and over bushes. The threadlegged bugs and marsh treaders are examples. As these creatures have no great economic significance so far as known, the wren

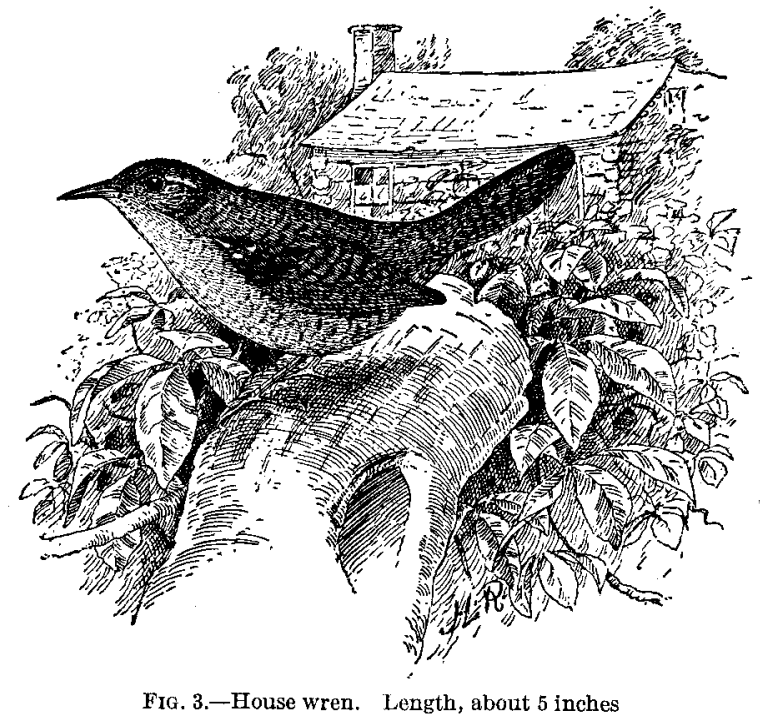

does neither good nor harm in eating them. The stinkbugs, negro bugs, and tree-hoppers and leafhoppers are harmful insects and in eating them and feeding them to its young the wren is an aid to the agriculturist.

Ants are eaten to the extent of 8.2 per cent of the yearly food, and in March constitute 22.67 per cent. Bees and wasps amount to 3.27 per cent. Flies a mere trifle in the food of the wren, are evidently left to the more fleet flycatchers and swallows. Spiders are acceptable and are captured every month in the season. The wren finds these when searching under piles of lumber or brush, stone walls, hollow logs, outhouses, and sheds. They aggregate 1.0.51 per cent of the food, and in March 32.5 per cent. Millepeds (thousand-legs) form a part (2.76 per cent) of the food of the first four months of the year, sixsevenths of them being eaten in April. Other creatures, as sowbugs and snails. were found in a few stomachs, but are negligible.-F. E. L. B. 
Both field observation and stomach examination show that the house wren consumes great numbers of noxious insects, thereby benefiting the farmer and gardener. The house wren is not known to damage any fruit or other crop, and in general food habits it is among the most beneficial of birds. One of its activities, however, and this is not reflected by stomach analyses, is its interference with the nesting of other birds. This has been prominently brought to the attention of bird lovers in recent years. House wrens have been observed by numerous competent ornithologists to pester other birds that, like itself, nest in cavities. They have also been seen to throw out the nesting material of other birds, and even to puncture their eggs, or kill their nestlings. There is no doubt about these occurrences, the only question being as to their generality and frequency. Some observers have not noted them, so that it is probable that these objectionable traits are not universal among wrens. It is possible, however, that these little busy bodies, although so praiseworthy as to food habits, have received too much encouragement in some localities. Where trouble is observed between them and other species of birds it is desired to foster, bird houses suitable for wrens only can be reduced in number, or, if necessary, removed entirely.-W. L. M.

\section{CAROLINA WREN 1}

The Carolina wren (fig. 4) is resident from the Gulf of Mexico north to the southern boundaries of Iowa, Illinois, and Connecticut in the breeding season, but in winter withdraws somewhat farther south. It is a bird of the thicket and undergrowth, preferring to place its nest in holes and crannies but when necessary will build a bulky structure in a tangle of twigs and vines. Unlike the house wren it does not ordinarily use the structures of man for nesting sites. It is one of the few American birds that sing throughout the year. Most birds sing, or try to, in the mating season, but the Carolina wren may be heard pouring forth his melody of song every month. The writer's first introduction to this bird was in the month of January when he heard gushing from a thicket a song which reminded him of June instead of midwinter.

This wren keeps up the reputation of the family as an insect eater, as over ninetenths of its diet consists of insects and their allies. In this investigation of its food there were examined 291 stomachs, representing every month. Their contents were made up of 94.18 per cent animal matter, nearly all insects, and 5.82 per cent vegetable, chiefly seeds. A very marked uniformity in the diet is noticeable, the winter season showing almost as great a consumption of insects as the summer.

Of the animal food, beetles amount to $\mathbf{1 3 . 6 4}$ per cent, all injurious except a few useful predatory ground beetles ( 1.71 per cent); two-fifths of these were eaten in December, presumably on account of scarcity of other insects. Many species of snout beetles, or weevils, were identified (4.29 per cent), but the most interesting economically is the cotton boll weevil, 31 individuals of which were found in 18 stomachs. Other beetles, like the 12 -spotted cucumber beetle, the striped cucumber beetle, the bean leaf beetle, and numerous so-called flea beetles, all more or less harmful, occur in many stomachs and form 7.64 per cent of the total food.

Ants (4.63 per cent) were found in the stomachs collected every month except September and in very uniform quantities. The greatest consumption was in July (8.81 per cent). For each of the 11 months, bees and wasps amount to about the same as the ants. Bugs, with one exception, are the most important item in the diet of the Carolina wren (18.91 per cent), and were eaten every month, with a good percentage for each. The maximum (32.16 per cent) was

1 Thryothorus ludooicianus. 
taken in February. The majority of the insects eaten were of the larger species, as stinkbugs, or soldier bugs, leaf-legged bugs, and leafhoppers. Four stomachs contained the chinch bug and in one there were 5 individuals. Scale insects destructive to oranges were found in one stomach.

Caterpillars and a few moths, the largest item in the food ( 21.73 per cent), were eaten every month with a good percentage for each. The month of greatest consumption is September, when they constitute more than one-third of the whole food (39 per cent). No special pest was observed, but as the Carolina wren is a small bird the caterpillars are usually so torn to pieces that the species can not be determined; and the moths eaten were so fragile as to be unidentifiable after the process of digestion had begun.

Grasshoppers and crickets, with a few other orthopterous insects, as cockroaches and their eggs, constitute 12.57 per cent of food of the Carolina wren and form a fairly large percentage of the food from July to the end of the year. The average consumption for these months is $\mathbf{1 9 . 6 5}$ per cent, while that for the first six months is only 5.49 per cent. As with many other birds the month of greatest consumption is August (26.9 per cent).

Flies do not appear very acceptable as food to the wren. None were eaten in January, August, or September, and comparatively few in the other months. The average for the year

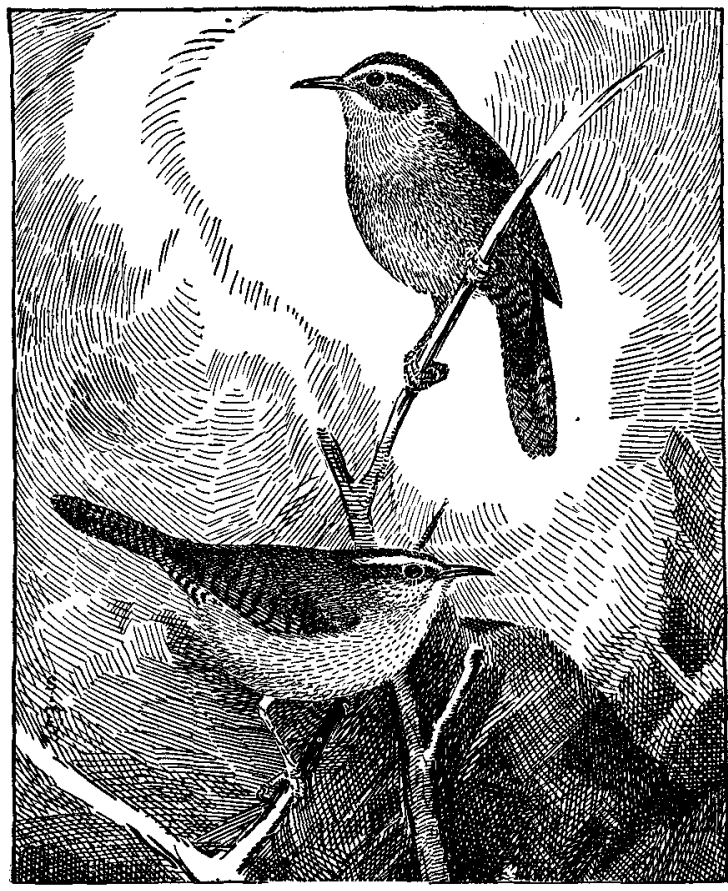

FIG. 4.-Carolina wren. Length, about $51 / 2$ inches is a trifle over 3 per cent. The sort mostly taken are the so-called "daddy long. legs," or crane flies.

Spiders are apparently very attractive to wrens in general, particularly to the Carolina wren, which probably finds them when investigating crannies of buildings, piles of lumber, or heaps of brush, as is its habit when looking for nesting sites, or when not pressed by other responsibilities. This wren eats spiders in every month, and in the five months from April to August to the extent of $\mathbf{1 6 . 6 7}$ per cent for each. In the remaining seven months spiders aggregate 6.16 per cent of the food, an unusual percentage; the average for the year is 10.54 per cent. Most wrens eat spiders more than do other birds, but the Carolina wren excels them all. Millepeds or thousand-legs, are eaten sparingly throughout the year (2.06 per cent) and none were taken in January, June, or September.

Animals other than insects, as sowbugs and snails, were found in a few stomachs, but constitute only 0.16 per cent. Vertebrate animals would hardly be expected to form part of the diet of so small a bird, but the Carolina wren eats them often. Remains of lizards were found in 14 stomachs, tree frogs in 8 , and a snake in 1 ; totaling 1.92 per cent. 
The great bulk of the vegetable food of the Carolina wren consists of various kinds of seeds, mostly of trees or shrubs. Of these, bayberry was found in 20 stomachs, sweet gum in 10 , poison ivy in 7 , sumac in 4 , pine in 2 , smartweed and other weeds in 7, and mast (ground up acorn) in 2. Besides these a few stomachs contained pulp which could only be identified as "fruit."

From this analysis of the food of the Carolina wren, it is evident that the farmer and fruit grower have not the slightest cause for complaint against the bird. It eats neither cultivated fruit nor grain, and does not even nest in an orchard tree; but it does feed on numerous injurious insects and enlivens the tangled thickets with its cheerful song for 12 months in the year.-F. E. L. B.

\section{MOCKING BIRD ${ }^{1}$}

The mocking bird (fig. 5) has always been held in such high esteem for its vocal powers that any attempt to add to its reputation by showing that its food habits also are in its favor may seem superfluous. The title of the mocking bird to rank among economic benefactors has not heretofore been quite clear, however, for, though it does considerable good in the destruction of harmful insects, it is said to eat much fruit, and where fruit raising is an important industry, as in the Southern States, particularly Texas and Florida, bitter complaints are made against it. In Florida, the bird is charged with attacking grapes and oranges, and in Texas it is asserted that figs must be added to the list of fruit it damages.

For the present investigation of the mocking bird's food 417 stomachs were available, and these disclosed 47.81 per cent animal matter to 52.19 per cent vegetable. This is more than twice the proportion of animal food observed in mocking birds from California. Perhaps the abundant fruit in that section proves too great an attraction for the birds to bother with insects. The stomachs of southeastern birds examined were very evenly distributed over every month. Most of the animal food is taken in May (85.44 per cent). Vegetable food attains its maximum in December and January ( 86.55 per cent each).

The important items in the animal diet are beetles, ants, bees, wasps, grasshoppers, caterpillars, and a few each of several other groups. Useful beetles, mostly predacious ground beetles ( 3.47 per cent), together with grasshoppers, show that the mocking bird must gather a considerable portion of its food upon the ground. Harmful beetles ( 7.38 per cent) are of sorts mostly found on leaves of trees, bushes, or plants which are the natural habitat of the mocker. Many of these were weevils, and among them were nine specimens of the cotton boll weevil, in six stomachs. About a dozen stomachs contained remains of the 12-spotted cucumber beetle. Many other species were identified which are nearly as harmful but not so well known.

Ants (4.46 per cent), found in $\mathbf{7 5}$ stomachs, again show that the mocking bird goes to the ground for at least a portion of his food. Bees and wasps ( 3 per cent) are mostly good flyers and must either be taken on the wing or picked from flowers, and it is in the latter situation probably that the mocking bird gets them.

True bugs are eaten so seldom by this bird that the item would not be worth mentioning were it not that one stomach contained remains of that notorious wheat and corn pest, the chinch bug. This insect has probably caused more loss to agriculture than any other in the United States. Although the percentage in the food of the mocking bird is insignificant, any bird that eats this pest deserves honorable mention.

Flies are apparently merely tasted and pronounced not good, for a trace of them is all that stomachs show. Grasshoppers, on the contrary, appear to be the favorite animal food. They are eaten every month and average 14.85 per

1 Mimus polyglottos. 
cent for the year. In July they rise to 43.33 per cent, but in February there is only a mere trace. All the other months make a reasonable showing. Insects of this group captured include true grasshoppers, locusts, and crickets, all harmful and some very much so, as, for instance, the Rocky Mountain locust or grasshopper, which devasted the upper Mississippi Valley a few decades ago.

Caterpillars (9.48 per cent) were found every month in the diet of the mocking bird with a reasonable percentage in all except October. The most were taken in August (23.89 per cent), though nearly as many were eaten in May. Among a host of others, all more or less harmful, was the cotton leaf worm, found in 23 stomachs, and the cotton bollworm, in 2 stomachs. This latter is not confined to the South, but preys upon corn, tomatoes, and other crops all through the central and northern portions of the country. A few insects other than those already discussed were found, but the percentage is insignificant. Spiders were eaten sparingly (less than 2 per cent) in every month except October. A few millepeds, crawfish, sowbugs, and snails also were eaten, but the most singular food consisted of three lizards and a small snake, found in four stomachs.

The predominant vegetable food of the mocking bird is wild fruit. This is eaten every month and totals 42.58 per cent for the year, or more than four-fifths of the vegetable portion. The maximum consumption (76.91 per cent),

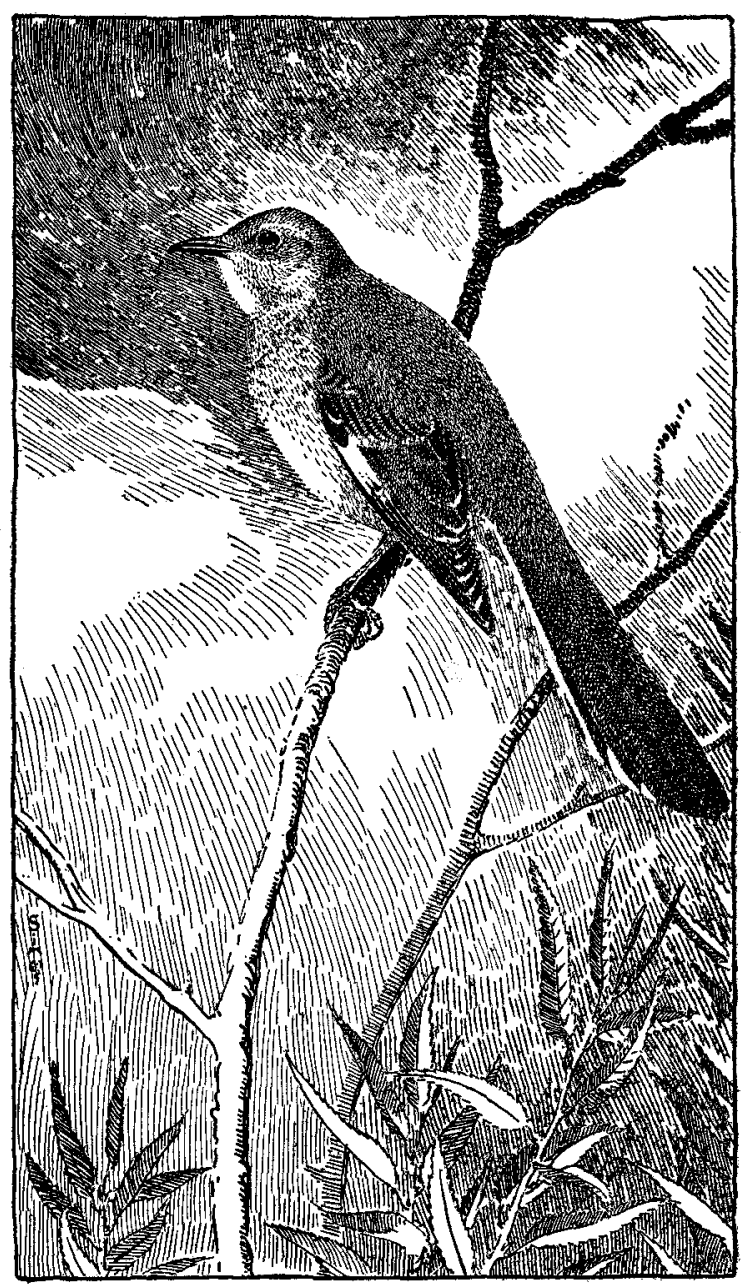

Fig. 5.-Mocking bird. Length, about 101/2 inches occurs in October. Wild fruit was found in 246 stomachs, and 76 contained nothing else. Thirty-five species of fruit were identified, and it is probable that more were present but too far digested to be recognized.

Those most frequently eaten were the different species of holly, smilax, woodbine, blackberry, pokeberry, elderberry, mulberry, and sour gum.

Domestic fruit ( 3.35 per cent), the great bulk of which was either raspberries or blackberries, was found in stomachs collected from May to August. Both 
of these berries grow wild in great abundance over most of the country and those eaten by the mocking bird are as apt to be taken from thickets and briar patches as from gardens. None of the larger fruits were certainly determined, but figs were found occasionally. A few grapes were identified, but these may as well have been wild as domestic. The mocking bird will probably do little harm to cultivated fruits so long as wild varieties are accessible and abundant. The remaining vegetable food was of no great importance, being made up of various weed seeds, sumac seeds of several species-including the poisonous (found in four stomachs)--petals of flowers, and rubbish. No grain of any kind was found.

There appears to be nothing to prove that the mocking bird eats domestic fruits to an injurious extent. It has in general enjoyed about the same place in the affections of the southern people that is held by the robin in the North, and judging by the results of this investigation it well deserves the place.-F. E. L. B.

\section{BROWN THRASHER 1}

Few birds excel the brown thrasher in sweetness of song, but it is so shy that its notes are not heard often enough to be appreciated. Its favorite time for

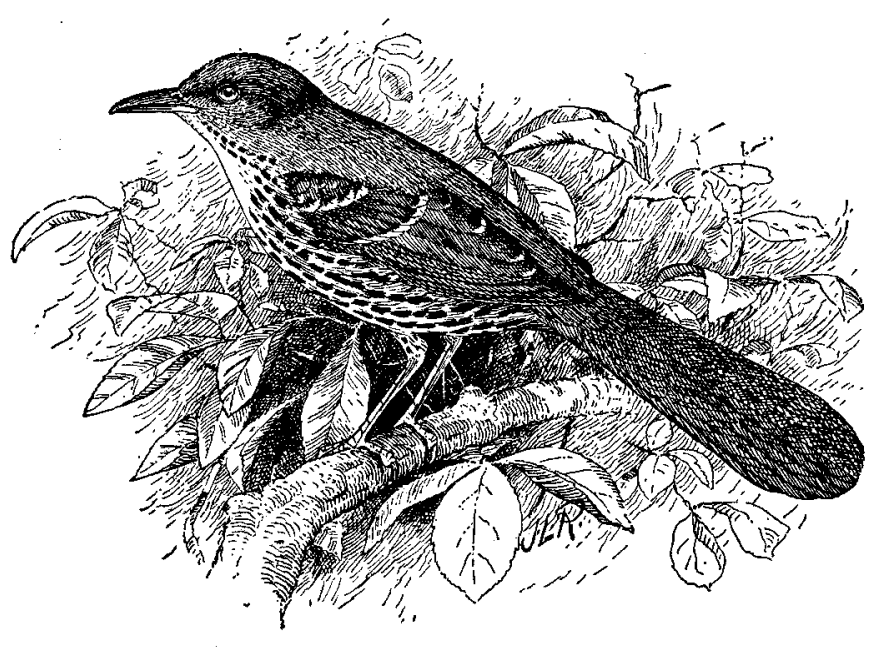

FIG. 6.--Brown thrasher. Length, about $11 \frac{1}{2}$ inches

singing is in early morning, when, perched on the top of some tall bush or low tree, it gives an exhibition of vocal powers that would do credit to a mocking bird. Indeed where the latter bird is abundant, the thrasher is sometimes known as the sandy mocker.

The brown thrasher (fig. 6) breeds throughout the United States east of the Great Plains, and winters in the South Atlantic and Gulf States. It occasionally visits the garden or orchard, but nests in swamps or in groves standing upon low ground, and sometimes builds in a pile of brush at a distance from trees. On account of its more retiring habits it is not so conspicuous as the robin, though it may be equally abundant.

The food of the thrasher consists of both fruit and insects. An examination of 266 stomachs showed 37.38 per cent animal and 62.62 per cent vegetable food, the former practically all insects.

1 Torostoma rufum. 
The most noticeable peculiarity in the food is that no one item is greatily in excess of others, while in the case of the yellow-billed cuckoo, for instance, caterpillars constitute more than half the food. With the thrasher the largest item is made up of beetles (18.14 per cent). A few of these (4.82 per cent) are of useful species, mostly predacious ground beetles. Others (13.32 per cent) are of a more or less harmful character, the great bulk being May beetles and weevils, or snout beetles. Among the latter is the notorious cotton boll weevil, found in six stomachs. May beetles, when in the grub stage, injure roots of grass and other plants. The 12-spotted cucumber beetle, another destructive pest, also was found in many stomachs. Beetles are eaten regularly throughout the year, although a little more from March to June than in other months.

Ants form a surprisingly small percentage of the yearly food (1.38 per cent) when the fact is considered that the thrasher gets most of its food upon the ground, where most ants live. The small destruction of bees and wasps ( 0.93 per cent) is not surprising, as the thrasher is hardly agile enough on the wing to catch such swift fliers. These three insects, however, are very evenly distributed throughout the year, each month showing a small percentage. Bugs, mostly stinkbugs with a few negro bugs, make up 1.54 per cent and are very regularly distributed. One bird taken in Illinois had eaten chinch bugs, but none were found in stomachs from farther south. Flies (1.76 per cent) are evidently not a favorite food of the thrasher, and nearly all of those eaten were taken in November. One stomach secured that month in a Mississippi cotton field was filled with flies except 6 per cent of fruit of "French mulberries"; the bird had probably found a colony of flies hibernating in a crevice and had devoured the whole lot.

Caterpillars (5.95 per cent) stand next to beetles in the thrasher's food, and are taken every month except November; that month, however, is represented by only five stomachs. Grasshoppers and crickets would seem to be very available to the thrasher, as the insects live on the ground, where also the birds get their food; but, unlike the meadowlark, these birds do not esteem grasshopper diet enough to go out in the sunshine to seek it. This food (2.43 per cent for the year) is taken to some extent every month, the maximum ( 8.5 per cent) in September.

A few insects of other groups are picked up occasionally. In all they amount to only one-fourth of 1 per cent. Spiders ( 0.58 per cent) are eaten now and then, and myriapods (thousand-legs) to a somewhat greater extent $(2.24$ per cent), but very irregularly, the maximum (8 per cent) in January. A few miscellaneous animals, like crawfish, sowbugs, snails, and angleworms, make up 1.26 per cent. Bones of lizards, salamanders, and tree frogs (in all, 0.92 per cent) were found in 11 stomachs.

Of the insects eaten by the brown thrasher there is only one class to which exception can be taken-the predacious beetles. That these insects render some service to man is beyond reasonable doubt, though some of them also do injury. Their destruction, then, is not an unmixed harm, but in any case the more numerous noxious insects eaten by the thrasher more than compensate for the useful beetles incidentally destroyed.

The vegetable food of this bird is nearly equally divided between fruit and a number of other substances, of which mast is the most prominent. Wild fruit, the largest item in the vegetable portion (19.94 per cent), was eaten every month in varying quantities, the month of maximum consumption (45.69 per cent) being September; January and February, with dried-up fruit from the last summer's crop, stand next. Altogether about 30 species of wild fruits or berries were identified in the stomachs. Those most eaten are blueberries, huckleberries, holly berries, elderberries, pokeberries, hackberries, Virginia creeper, and sour gum. Some seeds not properly classified as "fruit" were found, as bayberry, sumac-including some of the poisonous species-pine, and sweet gum. Seeds formed 3.97 per cent of the yearly food.

$414228^{\circ}-41-3$ 
Domestic fruit, or what was called such, was found in nine months, from April to the end of the year, most of it (53.19 per cent) in July. Raspberries or blackberries, currants, grapes, cherries, and strawberries were positively identified by their seeds, but as all of these grow wild, it is probable that much that is conventionally termed domestic fruit is really from uncultivated plants. The aggregate for the year is $\mathbf{1 2 . 4 2}$ per cent. Most unexpected in the thrasher's diet was mast, principally acorns, although some of it was so finely ground up that it was not possible to tell its exact nature. It is also somewhat a matter of doubt as to just where to draw a dividing line between mast and seeds, so that the proportion of each is somewhat uncertain. In the case in hand the total for the year is estimated at 23.72 per cent. Mast was eaten every month except August, but mostly in fall and winter-November, the month when acorns are abundant and fresh, showing the greatest quantity ( 57.4 per cent).

Grain (2.57 per cent) was found in the stomachs for six months, but in only February, March, and May were there noteworthy percentages. March shows 12.37 per cent, the other two slightly less. The grain was nearly all corn, with a little wheat, but from the season in which it was taken most of it evidently was waste.

The farmer has nothing to fear from depredations on fruit or grain by the brown thrasher. The bird is a resident of groves and swamps rather than of orchards and gardens, so that it comes but little into contact with the products of husbandry, and does not prey upon them extensively when it does. The useful insects that it eats are amply paid by its destruction of noxious ones.-F. E. L. B.

\section{CARDINAL :}

Vivacity, beauty, and vocal expertness are three outstanding traits of the cardinal, or redbird (fig. 7). Whether the eye is held by the vivid color that suggested the bird's name, or by the active, graceful movements, the raising and lowering of the crest, which when fully erect gives the bird an appearance of such keen attention, or whether the ear is charmed by the rich and varied songs, the impression produced is one of extreme pleasure.

Though somewhat shy, the cardinal does not entirely avoid the vicinity of homes. However, it prefers more secluded resorts. Shrubbery is its chosen haunt, the more tangled the better. Here the nest is built and the young reared, and here they spend most of their days. Higher trees are usually sought only under the inspiration of song.

Viewed from the economic standpoint the cardinal deserves favorable comment, as it does for its other high qualities. Its food is composed of about 29 per cent animal matter and 71 per cent vegetable. Among the insects eaten are a few that are beneficial, but at most not more than 2 per cent of the cardinal's food, probably less, consists of useful insects, while twelve times as much is made up of injurious species. Caterpillars are greatly relished, and among those discovered in the food were three pests of the cotton crop, namely, the cotton worm, the bollworm, and the cotton cutworm. Ninety-six of the last-named species were eaten by 31 cardinals from Texas cotton fields. Other caterpillar pests eaten are the purslane sphinx, zebra caterpillar, and codling moth.

Grasshoppers, together with true bugs, form more than one-tenth of the total food. These groups of insects comprise many injurious forms of which the cardinal takes due toll. Especially commendable is the destruction of scale insects, of which several different species were identified from the stomachs of 21 redbirds.

Beetles comprise more than a tenth of the whole diet. Among them, weevils are predominant. The acorn weevils, clover weevils, and billbugs, all injurious forms,

\footnotetext{
1 Richmondena cardinalis.
} 
are freely eaten, and the cotton boll weevil occasionally. Vine chafers of various species, the southern fig eater, and rose chafers are among other injurious beetles destroyed. Click beetles, cucumber beetles, strawberry root borers, plum and locust leaf beetles also are devoured by the cardinal. The bird has a record for feeding on many of the worst agricultural pests.

The vegetable food consists chiefly of weed seeds, but wild fruit and grain also are eaten to some extent. The grain, however, is largely waste, as it is taken only in winter. Wild fruit, or rather the seeds of wild fruit, which usually are extracted and the pulp rejected by the redbird, composes about one-fourth of the total subsistence. Wild grape seeds are favorites, but those of dogwoods, blackberries, hackberries, smilax, cherries, blueberries, elderberries, pokeberries, and juneberries, and the fruit of prickly pear, sumac, holly, redhaw, passion flower, Mexican mulberry, and palmettos also are eaten. Little, if any, attention is paid to cultivated fruits. Mostimportant among the items of vegetable food is weed seed. This forms more than a third of the total food. Seeds of smartweeds and bindweeds rank first in preference, and the seeds of the following troublesome weeds are freely eaten: Foxtail, bur, cockspur, crab and yard grasses, dodder, dock, sowthistle, plantain, tumbleweed, nail grass, lamb's-quarters, chickweed, sticktight, part-

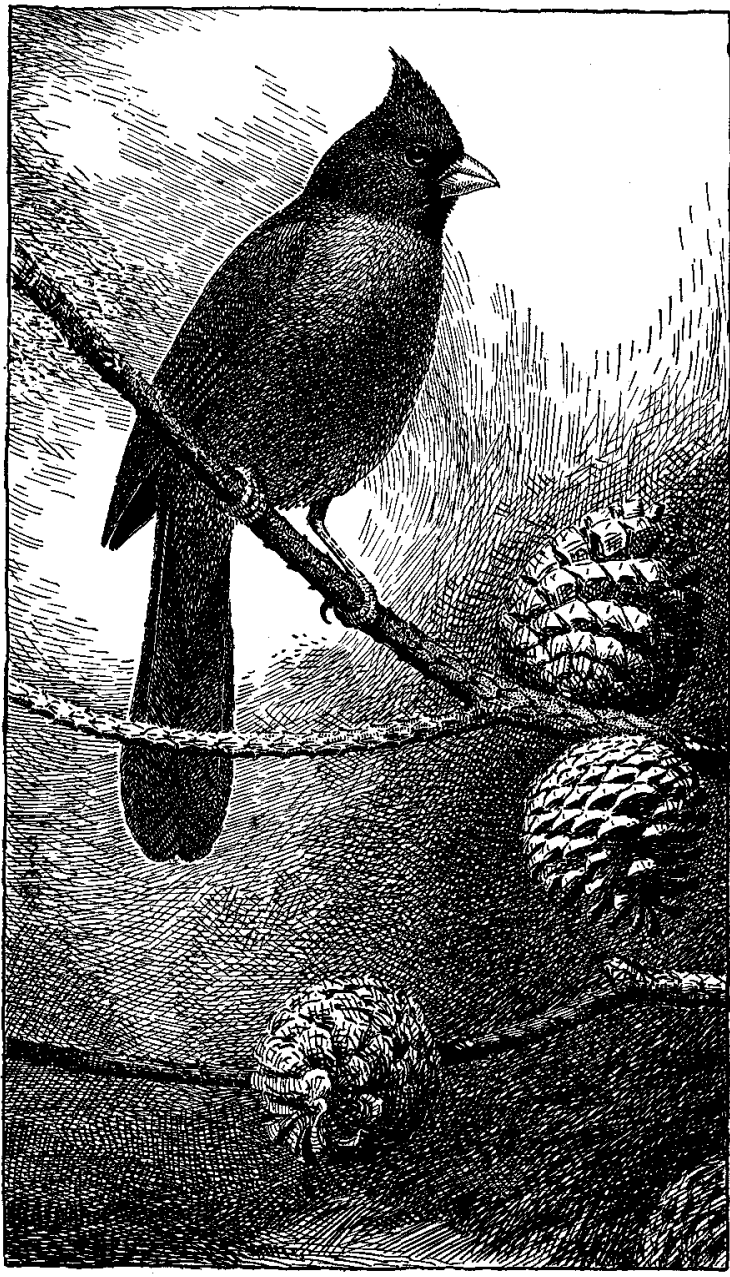

FIG. 7.-Cardinal. Length, about $81 / 4$ inches ridge pea, and buttonweed. The redbird occupies an important place among birds devouring weed seeds.-W. L. M.

\section{GRAY GROSBEAK}

The gray grosbeak, or parrot-bill, is about the same size as the cardinal, closely resembles that bird in song and general demeanor, and has similar nesting habits.

1 Pyrrhuloxia sinuate texane. 
Moreover, it frequents the same kind of country and is resident wherever found. In appearance, however, it is quite dissimilar.

In strong contrast to the glowing hue of the cardinal the general color of both sexes of the parrot-bill is light gray. The wings, tail, and long crest are suffused with dark red and the wings are lined with rose. This color also surrounds the beak of the male and extends over throat and breast in an irregular patch. The beak is yellowish and is very curiously modified, being short, thick, strongly curved, and apparently of great power.

The gray grosbeak comes into the lower half of Texas, not reaching, however, the extreme eastern part of the State.

Seventy-four stomachs of gray grosbeaks from Texas have been examined, 59 collected in August and 15 in September. Vegetable matter averages $\mathbf{7 1 . 1 9}$ per cent of the contents and animal matter 28.81 per cent.

Grass seeds constitute an average of 53.09 per cent of the total food of the birds examined, or more than five-sevenths of the vegetable food alone. Most important among them are foxtail and bur grass, which together amount to 43.59 per cent of the food. Since these grasses are among the most pernicious of weeds, the parrot-bill is more than welcome to all their seeds it desires.

The seeds of other grasses eaten are important, furnishing 9.51 per cent of the bird's subsistence. Among these are witch and crab grasses, most species of which are weeds, and yard or wire grass. Seeds of a spurge contribute 9.81 per cent of this grosbeak's fare, and other weeds, including bindweed, lamb'squarters, tumbleweed, sunflower, carpetweed, nightshade, vervain, and mallow compose 6.13 per cent.

While the parrot-bill consumes a smaller proportion of animal matter than the cardinal, it selects about the same things, the principal items being grasshoppers, caterpillars, and beetles. Neither parasitic hymenopterans nor predacious beetles were found in the stomachs examined, a showing much to the bird's credit. Only one useful insect had been eaten, it belonging to a queer neuropteroid genus, members of which are rare. They are predacious when adult, and when young are parasitic in the egg sacs of spiders.

The remaining animal food is composed of injurious species, many of them important pests. Beetles constitute 4.66 per cent of the food, weevils alone being 3.42. Of greatest interest among the latter is the cotton boll weevil, the most serious agricultural pest of recent years. While the gray grosbeak does not feed upon it regularly, nevertheless the habit of picking it up when occasion offers is highly commendable. Leaf beetles, bronzy wood borers, and longhorned beetles, all of which are destructive to forest and orchard trees, also were found in stomachs of this species.

Beetles, as a whole, are exceeded in the food of this bird by caterpillars, the latter constituting 10.32 per cent of the diet. One of the species identified-the cotton worm-has long been known as a great pest throughout the Southern States, and in certain years has caused a decrease in the crop of a quarter of a million bales, valued at $\$ 25,000,000$. Fourteen of the 74 gray grosbeaks examined consumed cotton worms, which averaged 39.1 per cent of their food. As many as 18 caterpillars were found in a single stomach. Another caterpillar enemy of the same crop-the cotton cutworm-also is freely devoured.

As beetles are less esteemed than caterpillars by the gray grosbeak, so also are the latter less liked than orthopterous insects. This group contributes 11.52 per cent of the total food, and includes both long and short-horned locusts and their eggs, 7 or 8 grasshoppers sometimes being secured by a single bird. True bugs, comprising stinkbugs and their eggs, eicadas, leafhoppers, and lantern flies come to about 1.5 per cent. All these insects are injurious and the bird does a service by feeding upon them. 
One parrot-bill was bold enough to swallow a large hornet. A few ants also were eaten, and these, together with spiders and snails, complete the list of animal food taken. Although this grosbeak is not conspicuously insectivorous, almost all the insects it eats are injurious.

The data at hand are insufficient to determine finally the exact economic status of the bird, but it may be stated with confidence that the gray grosbeak is almost entirely beneficial.-W. L. M.

\section{PAINTED BUNTING 1}

The male painted bunting (fig. 8) is one of the most brilliantly colored birds of the United States. The upper part of the head and neck are shining purplish violet, the middle of the back yellowish green, wings and tail purplish blue, and underparts and rump vermilion. The female is dark green above and yellowish beneath.

This little jewel has not failed to attract popular attention and in consequence has received a variety of common names. In Louisiana the French speaking people have called it nonpareil (unequaled), and le pape (the pope). The last name has been contracted to pop and varied as red pop. Spanish speaking citizens know the bird as mariposa (butterfly), and in English the bird has variously been named painted bunting or finch, paradise finch, Mexican canary, and Texas canary.

The painted bunting is not only distinguished in appearance, but also is one of the most pleasing

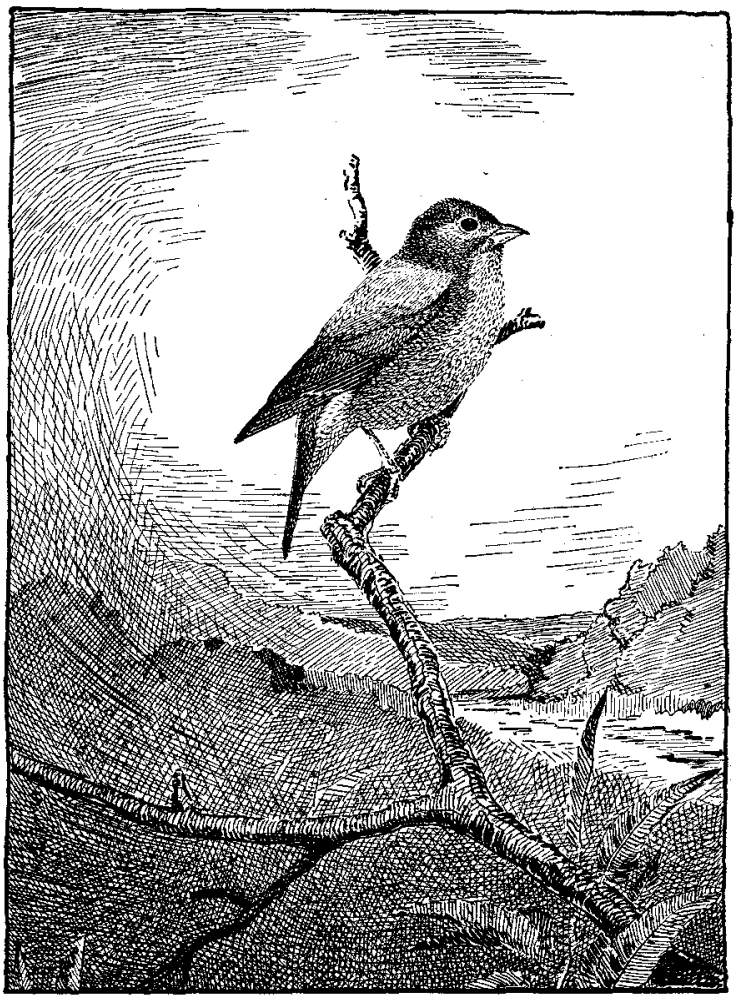

FIG. 8.-Painted bunting. Length, about 51/4 inches songsters among the finches. It is a persistent vocalist, and this characteristic, in addition to its beauty and activity, makes it a most desirable species for the vicinity of homes. Fortunately the bird is not averse to proximity to man, and its preference for shrubbery further adapts it to living about dooryards and gardens. The nest, though usually placed low, is well concealed, and the eggs number three to five.

Few complaints have been lodged against the painted bunting on the score of its food habits. It is said to eat rice at times, to peck into figs and grapes, and to bite off the tips of pecan shoots. In no case that has come to notice, however, 
has it been charged with doing serious damage. Certainly no such charge is supported by studies of the Fish and Wildlife Service, for no product of husbandry has thus far been found in any of the stomachs, 80 of which have been examined, all collected in Texas in July, August, and September. Averages for the July and August material only are here presented. Animal matter composed 20.86 per cent of the contents of these stomachs, and vegetable matter 79.14 per cent. Of the former, 2.48 per cent was made up of weevils, mostly cotton boll weevils. All insects of this group are destructive, but none more so than the notorious cotton boll weevil, and this species had been eaten by 18 of the 80 nonpareils examined.

Another enemy of the cotton crop attacked by these brightly colored little birds is the cotton worm. This insect was preyed upon to the extent of 3.14 per cent of the total food of the 80 painted buntings examined. Other insects eaten include grasshoppers, crickets, click beetles, leaf beetles, caterpillars, true bugs, and small hymenopterans. A few spiders and one snail also were taken.

The vegetable food is remarkable in consisting very largely of a single itemthe seeds of foxtail or pigeon grass. This is one of the worst weeds in the United States. The 80 painted buntings made over two-thirds (precisely 67.03 per cent) of their total food of its seeds. The seeds of other grasses composed 5.88 per cent of the food, grasses alone thus furnishing over nine-tenths of the vegetable portion. The other vegetable matter eaten consists largely of seeds of such weeds as amaranth, mallow, sorrel, and nail grass.

To sum up, practically all of the vegetable food of the painted bunting is of weed seeds, two-thirds of it being the seeds of foxtail grass, one of the worst weed pests. The animal food also is composed almost exclusively of injurious species, more than a fourth of it consisting of the two greatest pests of the cotton crop-the cotton worm and the boll weevil.-w. L. M.

\section{COMMON CROW 1}

Though not possessing the proverbially bad reputation of its kin of the Northern States, the crow (fig. 9) of the South is well known in a large part of the area of which this bulletin treats. Throughout the coastal region east of Texas it is intimately associated with its maritime relative, the fish crow, ${ }^{2}$ and in winter these two have much the same food habits.

The series of 108 stomachs available for examination, while too few to show accurately the food habits of the crow over so large an area, has verified much of the information gained from field observation. The food of the crow of the South is much like that of its northern relative, such differences as are observed being due to the relative abundance of certain food items in the two areas. The southern crow has many of the virtues of the northern bird, and, so far as the evidence at hand shows, certain corvine failings, as nest robbing and injuring sprouting corn, seem less pronounced.

Examination of stomachs revealed 31 per cent animal food and 69 per cent vegetable. Insects comprised a little less than a fifth of the yearly sustenance, and were made up of many of the common pests, as May beetles and their larvæ (white grubs), which were eaten in every month save two; weevils of several kinds; grasshoppers (nearly 5 per cent); and several species of caterpillars. Such beneficial insects as predacious ground beetles and bugs and parasitic hymenopterans formed less than 2 per cent.

Crustaceans, by far the largest part of which were crawfish, constituted an important food item (7.4 per cent). These creatures in some section of the South are the cause of considerable damage, especially to corn and cotton. A 
few mollusks, amphibians, and fish (about 4 per cent) indicate the aquatic feeding habits of these birds. Fragments of the shell of a hen's egg found in one stomach supply the only evidence of that objectionable trait of which the northern crow is so frequently accused. No remains of wild birds or their eggs were found.

In the vegetable food, corn and wild fruits stand out prominently. The former constituted about a fourth of the yearly subsistence, but a large portion was taken in winter when it must have been secured from outstanding shocks or picked up as waste. Such wild fruits as sour gum, poisonous and nonpoisonous sumacs, pokeberry, blackberries, greenbrier, and the like composed nearly' a third of the food, and were so prominent probably because of the great abundance of many of these plants throughout the South. Grain, other than corn, and a little cultivated fruit also were taken.

Field observation has shown that certain other items not revealed by laboratory examination enter into the diet of the southern crow. Watermelons are frequently damaged, and small gardens have suffered losses in peas, strawberries, and peanuts. Growers of pecans also have entered complaints against the crow.

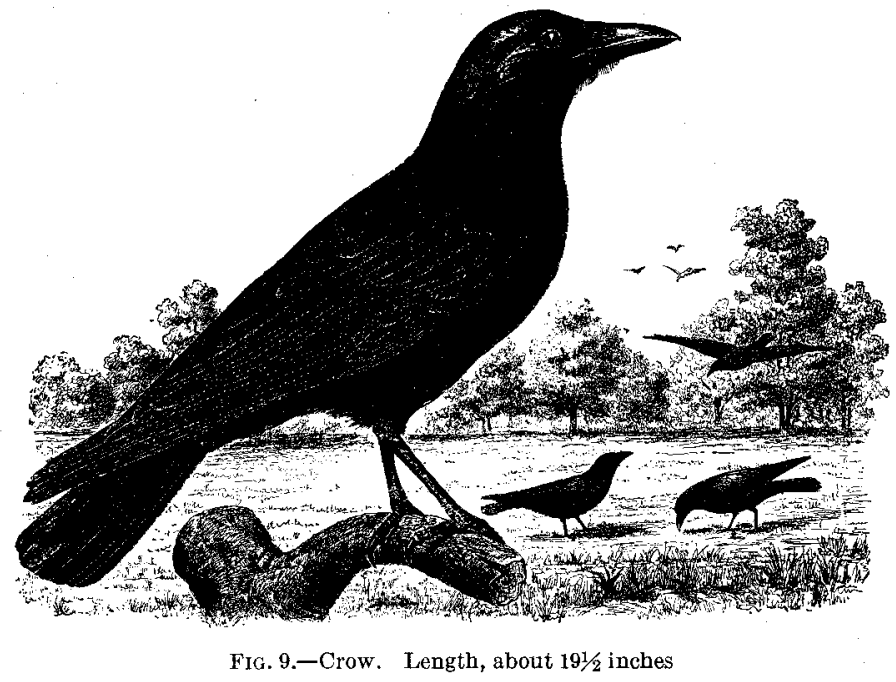

In many sections the bird has been credited with being a most potent disseminator of livestock diseases, especially hog cholera. While it may be one of many distributers of these diseases, ultimate remedies depend upon close attention to sanitation and quarantine rather than the destruction of all possible carriers. As a carrion eater, the crow renders the farmer an important service, especially in the South.

In view of the fact that corn pulling may be largely prevented by the use of deterrents, as coal tar upon the seed; that loosely made corn shocks, left standing long after the corn should have been properly stored, are a constant attraction for these birds; that damage to poultry and their eggs may be largely obviated by the proper housing of nesting fowls and the screening of chicks; and that much can be accomplished by scarecrows and other frightening devices, it appears that the legislation regarding the crow at present in force in the Southern States is satisfactory. Absolute protection is not afforded in any of these States. This allows the crow to be held in check when doing damage, yet the absence of extensive campaigns of destruction permits it to continue unmolested, in large measure, its good work in the destruction of insect pests in spring and summer.E. R. K. 


\section{BLUE JAY 1}

In the Southern States the blue jay (fig. 10), or "jay-bird" as he is more familiarly known, is a resident the year round, and in winter his numbers are swelled by migrants. Stomach examination shows that he possesses essentially the same food habits as his relatives in the North, while such differences as do occur are somewhat in favor of the southern bird. Complaints from agriculturists and sportsmen appear to be less frequent and severe in this area, while bird lovers have had less to say regarding the jay's habit of nest robbing, though this may be in part due to the fact that the movement to foster small insectivorous and game birds has not attracted so much attention here as in some sections farther north.

Examination of 184 stomachs indicates that animal food forms 31.9 per cent and vegetable 68.1 per cent of the total. Insects make up 26.5 per cent of the yearly sustenance, an increase of about 4.5 per cent over the northern bird; this is the strongest point in favor of the southern jay, especially since in this

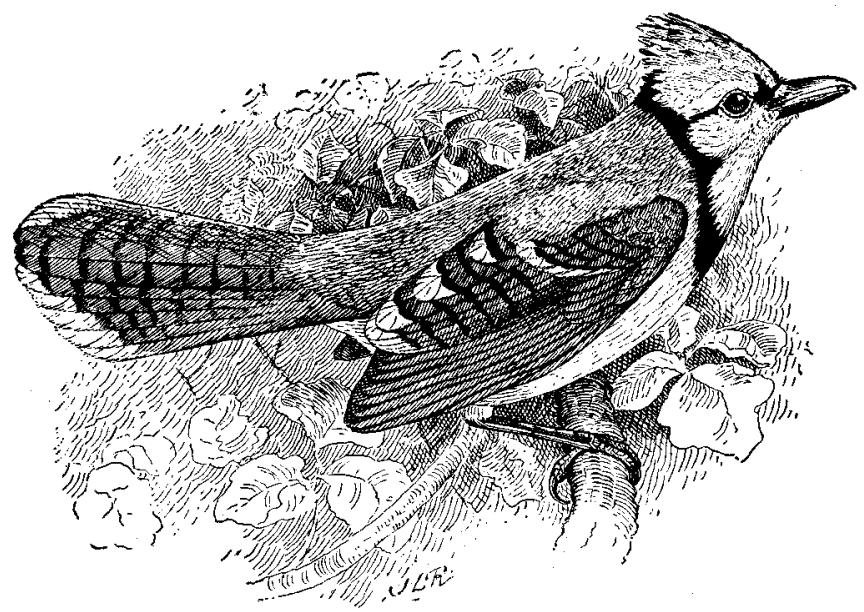

Fic. 10.-Blue jay. Length, about $11^{3 / 4}$ inches

iood are many of the most destructive pests, foremost among which are caterpillars and grasshoppers, in about equal quantity. Common articles in the blue jay's diet are scarabæid beetles, including May beetles, euphorias, and other related species, all of which, in one stage or another of their development, are highly destructive to vegetation. In May, when the first of these are abundant they comprise nearly three-tenths of the food. About wood lots the jay renders particularly valuable service in his choice of insect food. Important elements include both the flat-headed and round-headed wood borers, as well as numerous weevils, those feeding on pine predominating. Beneficial insects, including predacious ground beetles and bugs, and parasitic hymenopterans comprise about 9 per cent of the yearly food. The jay's liking for snails, which furnish an ample supply of animal matter at times when insects are scarce, appears to be akin to the southern crow's preference for crawfish. A few batrachians (toads and frogs), lizards, and even fish help out when hunting is not at its best. Of the 184 stomachs examined only one contained the egg of a small bird; shells of hen's eggs occurred in 13 of these, but as the jay is given to rummaging about rubbish piles, the source of some of this material may be thus explained.

I Cyanocitia cristata. 
A consideration of its vegetable food discloses evidence unfavorable to the southern blue jay. Of cultivated fruit and corn he takes considerably less than the northern bird, but on the latter food he lays heavy toll just at the time when the grain is in the roasting ear and ripening. In fact, in August, corn closely associated with the silk torn from the top of the ear was found in 11 of 15 stomachs, forming over 58 per cent of the monthly food. This item was also well represented in stomachs collected in July and September. But by far the most popular article of diet of the southern jay is mast, which composes nearly 46 per cent of the yearly food, and in January, when other food is scarce, runs as high as 84 per cent. Complaints against the bird on this score are few as yet, but this liking for mast may lead it into trouble with growers of cultivated nutspecans, for instance.

While there may be possibilities of the southern jay becoming troublesome locally, at present it can not be considered a serious menace to agriculture. Its insect diet during spring and summer, which includes many destructive species, more than compensates for the losses inflicted upon cornfields later in the season, or upon isolated orchards of cultivated nuts. - E. R. K.

\section{MEADOW LARK ${ }^{\text {1 }}$}

The meadow lark (fig. 11) is a familiar bird of grassland throughout the Eastern States. $^{2}$ Alike on meadows and savannas, its clear pipe may be heard in spring announcing the return of the season of procreation and growth. For its home it chooses level, slightly undulating land free from trees, and, if possible, with a supply of water near by. Its nest is built on the ground among the dead herbage of the last year's growth, is usually overarched to protect the eggs and the sitting bird from the weather, and is often so completely buried from sight as to defy detection by the most skillful searcher. The bird's preference for unmown fields covered with what farmers call "old fog" has given rise to the name of "old-field lark," by which it is known in many places.

The great bulk of the species is migratory from the Northern States, but from the latitude of Pennsylvania southward the bird is found throughout the winter, its numbers somewhat increasing farther south.

In the laboratory investigation 890 stomachs were examined, representing all the Southeastern States, and every month of the year. Analysis of the contents showed animal food, chiefly insects, 78.12 per cent; and vegetable, 21.88 per cent.

As illustrating this bird's vigilance in its search for insects, an instructive lesson may be drawn from the food of a group of six birds taken when the ground was covered with snow. The stomach having the least insect food contained 8 per cent; that with the most had 95 per cent; and the average for the six was over 47 per cent, or nearly half the total food. The insects consisted of beetles of several species, true bugs, grasshoppers, crickets, a few wasps, caterpillars, spiders, and myriapods. It thus seems evident that insects are essential to the diet of this bird and that great efforts are made to obtain them even under very adverse circumstances.

Of the insect food of the 890 birds, by far the most important elements were grasshoppers, long-horned or green grasshoppers, and crickets (27 per cent). In January they form more than 9 per cent of the total food, and increase rapidly until October, when they reach the surprising total of 56 per cent. During the succeeding months they decrease slowly, and in November still constitute 40 per

\footnotetext{
1 Sturnella magna.

${ }^{2}$ In the West a closely related form (Sturnella neglecta) has food habits very similar to those of the eastern bird.
} 
cent. It is extremely doubtful if any other bird will be able to show a better record for the destruction of grasshoppers. One stomach examined contained 37 individuals; but it should be borne in mind that the birds that form the subject of this paper were not collected from any region specially infested, but were gathered from all parts of the Southern States, and of the whole number, 466 contained grasshoppers.

Beetles of many species stand next to crickets and grasshoppers in importance, and constitute nearly 18 per cent of the annual food. One of the most harmful of these is the family of the May beetles or leaf chafers, the average consumption of which amounts to about 9 per cent for the year, and the greatest, 28 per cent, in May. Most of these are dung beetles, but remains of the well-known May beetles were found. Snout beetles, or weevils, form a small but very constant element of the food (about 4 per cent). Beetles belonging to about a dozen other families collectively constitute about 3 per cent of the whole food. Of importance in considering the diet of every bird is the extent to which it eats

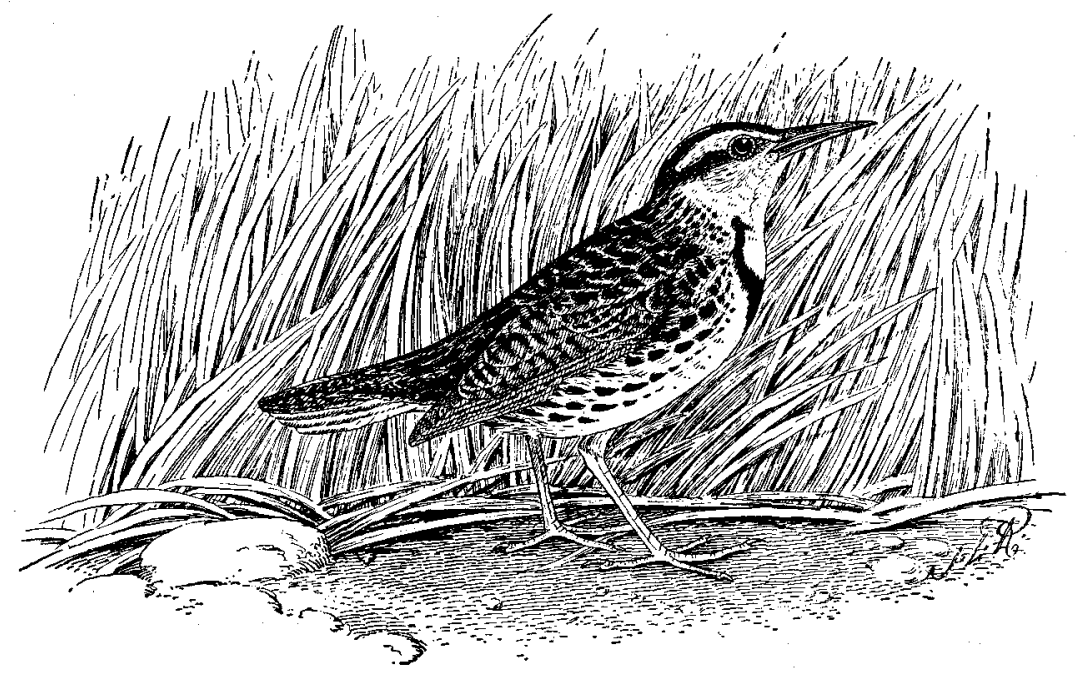

FIG. 11.-Meadow lark. Length, about $10^{3} / 4$ inches

predacious ground beetles. From its habits the meadow lark might be expected to feed largely upon these beetles, as they live upon the ground for the most part and are very abundant. Examination shows that these insects constitute somewhat more than 11 per cent of the food of the year. When it is considered how exclusively the meadow lark feeds upon the ground, this is certainly a very moderate exhibit and would seem to indicate that the bird does not especially seek for these beetles but simply eats such as fall in its way.

True bugs are eaten with fair regularity by this bird throughout the year, averaging 3 per cent of the food of the season. The greater number are of the family of stinkbugs, some of whose members are familiar (by taste) to many who have eaten raspberries from the vines; these will wonder at the taste of a bird that can habitually eat such highly seasoned food. Three specimens of the notorious chinch bug were found, and it is gratifying to know that the meadow lark will eat this insect which has done millions of dollars damage in this country.

Caterpillars, or the larvæ of butterflies and moths, form a very considerable portion (nearly 13 per cent of the food of the meadow lark; but, as with most 
other birds, the adults are rarely eaten, only 3 small moths having been found in as many of the 890 stomachs. Caterpillars were found in every month, and even the stomachs taken in December show over 2 per cent. The maximum (28 per cent) is attained in May.

Spiders and myriapods (thousand-legs) are eaten freely, and aggregate nearly 3 per cent of the food. Other insects eaten include flies, found in a few stomachs; a dragonfly in one; an earwig in one; and a common cattle tick in one. Snails or fragments of their shells were found in seven stomachs, sowbugs in two, a small crustacean in one, and the bones of small frogs or toads in three. These last were from stomachs taken in Florida and do not seem to be a favorite food.

The vegetable food of the meadow lark comprises 21.88 per cent of the total and may be roughly divided into fruit, grain, and weed seed. Fruit is mostly of wild species and amounts to less than 2 per cent. Grain of three kinds-corn (the favorite), wheat, and oats-constitutes a little less than 9 per cent, and was mostly taken in winter, showing conclusively that it was waste. No sprouting grain was found. Weed seeds, chiefly ragweed, barngrass, smartweed, sorrel, mustard, amaranth, and gromwell (about 7 per cent), like the grain, were mostly eaten in winter. In the analysis of the stomach contents clover seed was especially looked for, as the meadow lark has been accused of eating this to an injurious extent, but it was found in only six stomachs and only a few seeds in each-only one seed in some stomachs.

Stomach analysis does not indicate that grain is preferred to weed seeds. The quantity of each taken is practically the same and in such a grain-raising country as this it can not be urged that this food is less easily obtained than the seeds of weeds. When meadow larks collect in flocks, as they sometimes do, they may do some damage to grain, but at the time of the harvest of wheat and oats they are not thus congregated, and the stomach records show that at that season practically none of these grains were found, it being the time when insects were most abundant and constituted nearly the whole food.

Recent investigations in South Carolina, however, have substantiated accusations that the meadow lark is guilty of destroying sprouting corn. Similar complaints have come from time to time from other points in Southern States as far west as Texas. This habit seems to be confined to the migrating or wintering flocks before they have broken up for the breeding season and is probably occasioned by a scarcity of other available food. North Carolina seems to be the most northerly State in which this objectionable trait of the meadow lark manifests itself. Corn planted in March is most susceptible to attack and cases may be frequently encountered where whole fields must be replanted, resulting in a delayed and less profitable crop. In attacking the sprouts the birds usually drill a small conical hole down to the germinated kernel, which they eat, leaving the tender sprout exposed to the withering effect of sun and air.

Unfortunately for the meadow lark, its body is plump and its flesh well flavored, and as it is easily killed the temptation is too great for some persons to resist. But it is most frequently a case of "killing the goose that lays the golden eggs." The small portion of food that the creature's body yields is as nothing compared with the good the bird does when alive. The tendency to treat the meadow lark as a game bird is far too general, and every farmer on whose land it is found should rigidly protect it and allow it to breed undisturbed. When its numbers have so far increased as to render it dangerous to crops will be soon enough to begin the thinning-out process, but that day is still far distant in most parts of the country,-F, E, L, B. 


\section{BOAT-TAILED GRACKLE}

The boat-tailed grackle (fig. 12), the largest of the blackbirds in the United States, inhabits the South Atlantic and Gulf States from Virginia to Texas but is not found at any great distance from the coast.

In a general study of its food habits made by the Biological Survey there have been examined 247 stomachs from Florida, Alabama, Mississippi, Georgia,

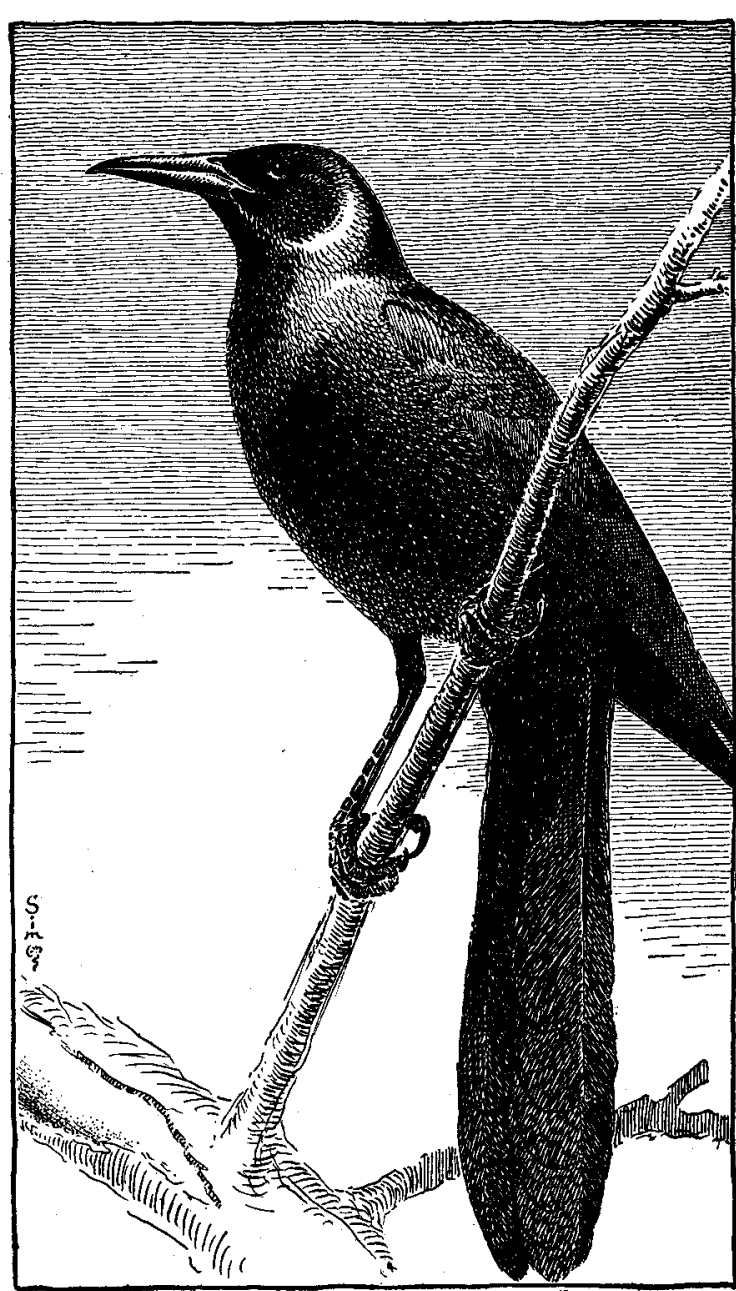

Fia. 12.-Boat-tailed grackle. Length, about 16 inches and Texas, representing every month in the year. The food consists of 47.45 per cent animal matter and 52.55 per cent vegetable. The former is made up of insects and crustaceans, with a few lizards, toads, frogs, small mammals, etc. Crustaceans make up more than a third of the animal food (16.81 per cent of the total) and consist of crawfish, crabs, and shrimps, a true seashore diet. No insects appear to be specially sought. Predacious beetles (3.23 per cent) are taken mostly in fall, and other beetles are found to some extent, but no family is conspicuous. Grasshoppers are eaten in July and August (34.47 and 30 per cent, respectively) but very few in any other month. The average for the year is 7.76 per cent. Six birds taken in Texas in September are worthy of special mention from the fact that they had all eaten cotton bollworms in quantities varying from 26 to 93 per cent of the food. A few other insects and remains of small vertebrates are frequently found in the stomachs but do not form important elements.

Grain (35.65 per cent), all but a mere trace of which is corn, composes part of the food of every month except May-the only stomachs collected in this month came from a rice field near Savannah, Ga. In each month except May and November corn constitutes more than half the vegetable food. October shows the greatest quantity ( 71 per cent of the total food), but as only five stomachs

\footnotetext{
1 Cassidix mexicanus major.
} 
were taken in this month this result can hardly be regarded as a fair average. The pulp of some large seed or nut, not otherwise identified, was next in importance to corn. Remains of figs in several stomachs and wild grapes in one indicate that fruit is eaten, though sparingly. No weed seeds were found.

It is thus evident that no salient points in favor of the boat-tailed grackle have come to light. In its insect food it has no pronounced preferences, and while it does not cause great havoc among useful insects, it.does not prey extensively upon harmful ones. In common with most other land birds, it eats grasshoppers freely in July and August, and shows a taste for caterpillars as well. The animal food it decidedly prefers is small maritime crustaceans, and these, so far as the interests of agriculture are concerned, are entirely neutral. In its vegetable diet, the bird certainly does not commend itself to the agriculturist. Its preference for corn is marked and shows no variation with the change of season. That it visits the growing crop for its supplies is evident from the fact that much of the corn found in the stomachs during early summer is "in the milk." In any locality, therefore, where this grackle is abundant it must almost necessarily be harmful to the corn crop without rendering any well-defined service in return.

Studies made in 1925 and 1926 in the rice area of Louisiana revealed the boattailed grackle to be seriously destructive to rice only in a narrow zone bordering the southern edge of the rice belt. Damage resulted principally from the bird's feeding on shocked grain. Here it also had redeeming food habits through its feeding on the sugar-cane beetle, ${ }^{1}$ the closely related rice beetle, ${ }_{2}^{2}$ weevils, grasshoppers, plant-feeding bugs, and caterpillars.-F. E. L. B. and E. R. K.

\section{BLUEBIRD 3}

Typical of all that is pleasing in bird life generally, the bluebird (fig. 13) is especially cherished wherever it is found, and on esthetic grounds alone is carefully protected. It ranges in the breeding season throughout the United States east of the Rocky Mountains, and remains in winter as far north as the southern parts of Illinois and Pennsylvania. It is one of the most domestic of our wild feathered friends and readily takes possession of the box erected for its accommodation where it can be safe from cats and other prowlers, or utilizes crannies of farm buildings for its nest; its original homes, however, were in such places as deserted woodpecker holes or cavities in old stumps. These birds are usually abundant wherever found and their numbers are maintained by the rearing of two and frequently three broods a year, with from four to six young in each. The food supply for such large families may well concern the farmer, and he will be interested to learn what these birds relish most.

For studying the food of the bluebird 244 stomachs from the Southeastern States were available, and the contents, 58.51 per cent animal food and 41.49 per cent vegetable, well demonstrate that the bird is as deserving of protection on economic grounds as it is for esthetic reasons.

In the animal food the largest portion is made up of orthopterous insects (grasshoppers, crickets, and katydids), totaling 20.53 per cent for the year. Most insects of this group are harmful and at times very destructive. Second in importance in the diet are beetles ( 18.79 per cent), made up in part of useful ground beetles ( 10.38 per cent of the total food), but in this item also are May beetles ( 3.9 per cent), weevils, or snout beetles (1.13 per cent), and miscellaneous related forms ( 3.38 per cent). The useful beetles are sometimes eaten in such numbers 
as to detract from the esteem in which the bluebird is held, the month of May, for instance, charging them against the bird to the extent of 36.61 per cent of the food, and every month recording them in such quantities as to indicate that they are very palatable to the bluebird. Few birds exceed this record of destruction of useful beetles, but it must be remembered that for the year they form only about one-tenth of the food, and that the remaining food shows that insects as a whole are attacked so impartially that the balance of nature is not disturbed, and while one kind of insect life is not exterminated another is not allowed to become superabundant; grasshoppers, for instance, enter the food of the bluebird about in proportion to their abundance.

The group third in order of importance in the animal food contains the many forms of eaterpillars, including a few moths ( 9.59 per cent). Chief among these are the owlet moths, the larvæ of which are the well-known cutworms, but there are also included hairy caterpillars and the "yellow bear." The rest of the animal food is made up of flying insects, as wasps, bees, and flies, in small quantities,

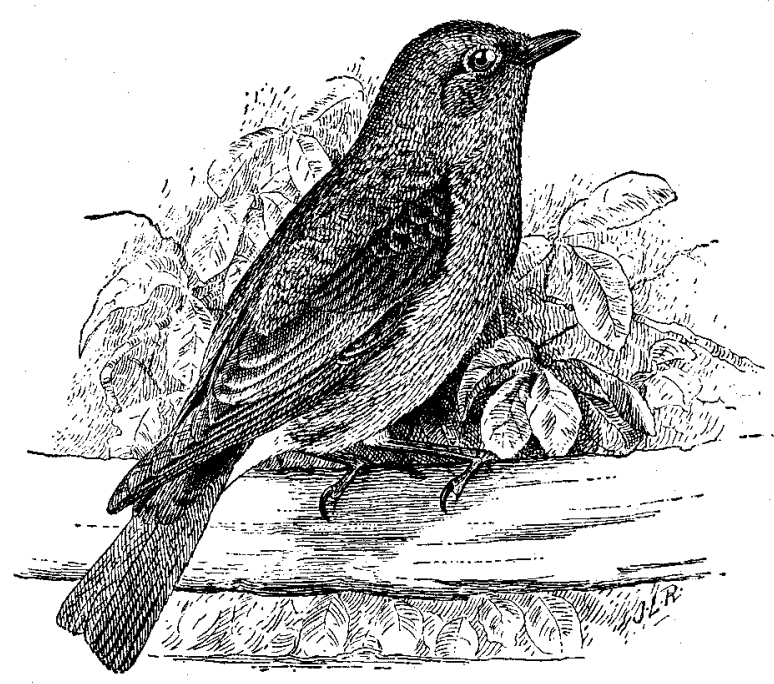

FIG. 13.-Bluebird. Length, about 7 inches for the bird is not very active on the wing; of ants and bugs among which latter stinkbugs predominate; remains of chinch bugs, detected in one stomach; a few spiders (2.47 per cent); still fewer myriapods, or thousandlegs (1.23 per cent); a mere trace of sowbugs and snails; and a few bones of lizards and tree frogs.

The vegetable food consists largely of fruit obtained from pastures, swamps, and hedgerows, rather than from gardens and orchards. Prac-

tically all the domestic fruit taken was secured in June and November, and the only cultivated species identified were cherries and raspberries or blackberries. In December, wild fruit forms two-thirds of the monthly food, but this item decreases gradually each month, and in May no fruit of any kind is taken. The yearly average is about a third of the total food. As fruit is taken chiefly in winter, it follows that it is eaten to tide the bird over until insects are again abundant, partly taking the place of seeds in the winter diet of birds in general, though seeds, too, are occasionally and sparingly eaten by the bluebird. Among them are seeds of sumac of both harmless and poisonous kinds, bayberry, and a little indeterminate vegetable refuse and rubbish, together averaging 7.21 per cent of the yearly food.

The bluebird has never been accused, in the writer's knowledge, of objectionable habits, and cultivated crops are not only safe from its attacks, but are benefited by its ridding them of an overabundance of harmful insects. In spring and early summer, when berries and small fruits are at their best, the bird subsists upon insects to the extent of five-sixths of its food. Its fruit-eating period is from late fall to early spring, when insects are scarce and waste fruit available. The point that has been urged against the bird, its destruction of predacious beetles, is a harmful trait more apparent than real, inasmuch as its record on all 
other lines is absolutely in its favor. Field observation and laboratory analysis of the food fully justify the high esteem in which the bird is held, and there is not the slightest excuse for persecuting it or withdrawing from it the smallest degree of protection.-F. E. L. B.

\section{CAROLINA CHICKADEE 1}

The Carolina chickadee (fig. 14) ranges through the southern portion of the United States from the Atlantic to the Rockies and north to the Ohio River and to some extent beyond.

Its nest is built in hollow trees or posts or in boxes set up for its special accommodation. A bird of forests and groves, it is not found on treeless areas, and does not often alight upon the ground. From this it follows that its food is mostly of the kind that can be taken on trees or bushes, and therefore, excludes such ground-inhabiting insects as ants and grasshoppers.

The study of the food habits of the Carolina chickadee is based upon an examination of the contents of 210 stomachs collected in the Southeastern States. The food consisted of 71.94 per cent animal matter and 28.06 per cent vegetable, the former being made up of insects and spiders with a few sowbugs,found in one stomach, and the latter of berries and several kinds of seeds.

Beetles, being rather terrestrial in habit, escape the chickadees to some extent, forming only 3.67 per cent of their food. Nearly half of these were snout beetles, or weevils, of which practically all

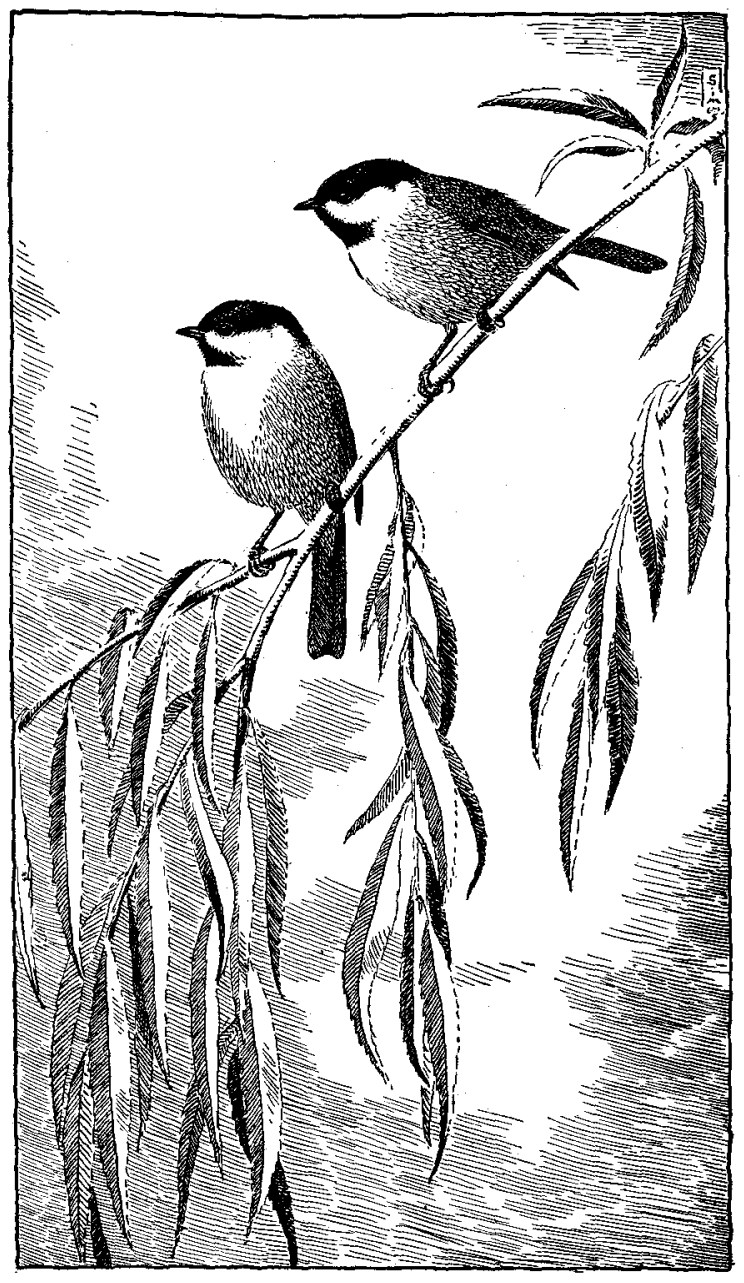

FIG. 14.-Carolina chickadee. Length, about $4 \frac{1}{2}$ inches species are more or less harmful and many are pests. The predacious ground beetles apparently elude these birds completely, for not a trace of one was found in any of the 210 stomachs.

A few ants were taken in the months from February to June, except May, but the average for the year is only 0.36 per cent. Bees and wasps (4.48 per 
cent of the food of the year) were taken oftener and more regularly. The month of greatest consumption was February, which would appear to be rather early for bees and wasps to be out extensively, and March stands next.

Bugs seem to be a favorite food in the four months from April to July, during which the great bulk is eaten. The average for these months is 15.13 per cent. but for the whole year it is only 5.68 per cent, as bugs were eaten in only three of the other eight months and then but sparingly. This item of food is made up of stinkbugs, shield bugs, leafhoppers, tree-hoppers, plant lice, and scales. While no special pest was noted, nearly all of these are harmful and especially the last two, of which there are hundreds of species and nearly every plant has its own peculiar form.

The real food of the Carolina chickadee consists of moths and caterpillars. Moths were found in only 1 stomach, their pupæ in 16, their eggs in 20 , and their larvæ (caterpillars) in 138, or about two-thirds of those examined. The month of greatest consumption is October, when they amount to more than three-fourths of the food (78.1 per cent). The month of least consumption is December, when they still aggregate more than a tenth of the yearly food (11.74 per cent). The average for the year ( 44.42 per cent) is exceeded by cuckoos, but by few if any other birds. Chickadees have a habit of beating their prey to pieces on a branch of a tree before swallowing it, so that the stomachs contain only fragments not easy to identify. It is probable that in these were many notorious pests, for the pupæ of codling moths were recognized in five stomachs and the eggs that produce one of the tent caterpillars in two.

Like many other tree-inhabiting species, the Carolina chickadee eats very few grasshoppers, but some were taken irregularly through the year (1.04 per cent). In five months, including August, the grasshopper month, none were eaten at all, and but few at other times. So far as stomach records show no genuine grasshoppers were eaten, but only some of their allies in their lowest or first stage, viz, the egg. In 11 stomachs were found the eggs of katydids; in 5 the egg cases of cockroaches; in 1 a grasshopper's egg; and in another a cricket's jaw.

Flies are practically ignored. What were probably the eggs of $\dot{a}$ crane fly were found in one stomach, but no adult flies were noted.

Spiders seem very palatable to the chickadee, being eaten every month and showing a higher percentage (10.9 per cent) in the stomachs than any other animal food except caterpillars. In five stomachs collected in March they amount to 44.6 per cent, but a greater number of stomachs would probably modify this record. One stomach was practically filled with the remains of sowbugs. These appear to be the only animal food eaten that can not be obtained from a tree, shrub, or weed, and it is not clear how the chickadee could get them, for sowbugs are essentially terrestrial in habit and are usually found under a stone, clod, or mass of practically decayed vegetation. A few bones and other tissues of a small unidentified vertebrate taken in June complete the animal food.

The vegetable food of the Carolina chickadee consists chiefly of fruit and seeds. Blackberries or raspberries, found in two stomachs; blueberries, in one; and fruit pulp not further identified, in five, constitute 2.17 per cent of the food for the year. Seeds of poison ivy (10.07 per cent for the year) appear to be a favorite food in the colder months, but only the waxy coating is eaten. This is taken off and swallowed and the real seed rejected, so that the bird does not aid in the distribution of this noxious plant as do so many birds that swallow the seeds and afterwards either disgorge them or pass them through the alimentary canal to fall and germinate in a different locality. 
Other seeds, most of them so broken and ground up as to be unidentifiable, were eaten to the extent of 12.38 per cent, chiefly in the colder months. In nine stomachs taken during this season were pieces of liverwort, a plant of the lower order that grows upon the bark of trees or damp rocks. This seems a very curious food for a bird, and is probably taken when other supplies are scarce.

In a résumé of the food of the Carolina chickadee, one is impressed with the fact that a large proportion consists of the eggs, pupæ, and larvæ of noxious insects. As an enemy of caterpillars the bird has few peers. It also destroys a great many of those two pests of horticulture, plant lice and scales.-F. E. L. B.

\section{TUFTED TITMOUSE 1}

The tufted titmouse inhabits the whole of eastern United States from the Gulf to southern Iowa and northern New Jersey. It is contented with various kinds of surroundings and will nest as readily in a box erected in the dooryard or garden as in the midst of the deep forest. Its preferred nesting site is an old woodpecker-hole or an unoccupied box put up for a wren, and it usually remains in the vicinity of its nest during the year. It is a rather noisy bird and keeps up its monotonous cry with tiresome iteration. In winter small flocks assemble, probably family groups, and ceaselessly wander about the forest in search of food, scrambling about the trunks and larger branches of trees for hidden insects and their eggs. At such times, they are very tame and pay little attention to human intruders. At the approach of spring they separate into pairs.

For investigating the food of the tufted tit 186 stomachs were examined. These were too few and too irregularly distributed through the year to afford more than an approximation of the bird's economic worth. The food consisted of 66.57 per cent animal matter to 33.43 per cent vegetable. Contrasted with the food of the brown thrasher, in which no one article predominates, that of the tufted tit includes one item, caterpillars, which forms more than half the animal food, and two items, caterpillars and wasps, which are more than half the whole food.

Beetles make up 7.06 per cent of the subsistence, and of these only one-tenth of 1 per cent are useful species. More than two-thirds of the beetles (4.94 per cent) are snout beetles, or weevils. Among these the cotton boll weevil was found in four stomachs. The remainder (2.02 per cent) are of various families, all harmful.

Ants are eaten by this tit occasionally, but in the light of present evidence can not be considered a standard article of diet. Other hymenopterous food, i. e., bees, wasps, and sawfly larvæ, is eaten much more extensively (12.5 per cent), and as the saw tly larvæ predominate, the winged forms are not in the majority among the hymenopterans. The tufted tit, like the cuckoo in this respect, takes many sawfly larvæ when searching for caterpillars.

Bugs, principally stinkbugs, tree-hoppers, and seales, or bark lice, are eaten to a moderate extent ( 4.03 per cent) in 7 of the 12 months. Their absence from September to January, inclusive, would probably disappear with a greater collection of stomachs. Scales were the most numerous of the bugs, and in two stomachs specimens of the European fruit scale were identified. In one stomach, and this taken in January, were found the remains of a single fly; from this record it may safely be asserted that flies are not a favorite food of this bird.

Caterpillars apparently stand at the head of the dietary of the tufted tit, aggregating more than half the animal food for the year (38.31 per cent). They were eaten in every month but one-November. Of six stomachs taken in that

1 Bsolophus bicolor. 
month not one contained caterpillars, although both October and December stomachs show fair percentages. The one stomach taken in August gives that month the highest of any, 76 per cent. The titmouse is so small a bird that the caterpillars eaten are mostly torn in pieces before being swallowed, thus making identification difficult or impossible, but the cotton leaf worm was identified in one stomach. No grasshoppers or crickets were found. The only traces of orthopterous insects ( 0.42 per cent) were eggs of katydids, egg cases of cockroaches, and a jaw and an ovipositor thought to be of a grasshopper.

Spiders are picked up in moderation and rather irregularly. They are evidently a makeshift food, and were found in 40 stomachs collected in May (12.67 per cent), 7 stomachs in June (a mere trace), and 3 stomachs in July (16.33 per cent). Thousandlegs were not found. A few snails make up the remainder of the animal food.

Of the vegetable food, corn was discovered in one stomach, evidently taken on trial. Fruit was eaten to a moderate extent ( 5.15 per cent), mostly in midsummer and included raspberries, blackberries, and strawberries, which might have been of cultivated varieties, but probably were not. The wild fruits were such as grow by the wayside and in swamps, as elderberries, hackberries, blueberries, huckleberries, and mulberries. Seeds of various kinds, as sumac-including poison ivy-bayberry, or wax myrtle, aggregate 4.07 per cent. It is difficult to draw the line between broken seeds and mast in stomachs of the tufted tit, but, together considered as mast, these form more than two-thirds of the vegetable food. While largely composed of acorns, there is no doubt that chinquapins and beechnuts and many smaller seeds enter into its composition. As thus defined, mast amounts to 23.4 per cent of the whole food, comprising 95 per cent of that eaten in November, 50.42 per cent in January, and 55.97 per cent in February; in fact, it is the principal vegetable food eaten from August to February. That such small birds should crush such hard nuts as acorns and chinquapins is surprising, but the broken fragments found in the stomachs well demonstrate their ability.

From the foregoing discussion of the food of the tufted titmouse, it is evident that the bird is beneficial, and so far as this investigation shows it has no bad habits or tastes to offset the good it does by its destruction of noxious insects. If encouraged, it becomes domestic, and, like the wren, lives about the garden and helps to keep in check the hundreds of insects that prey upon the products of cultivation.-F. E. L. B.

\section{PURPLE MARTIN 1}

The purple martin (fig. 15), or house martin, as it is more commonly called, occupies the whole of the United States during the breeding season, but is rather more numerous in the South. Its habit of building nests in boxes provided for its express use has caused it to become the most domestic of all swallows. Besides houses erected for them, the birds do not disdain gourds hollowed out and hung on poles. As their food is taken on the wing, clear, open lands, especially low moist meadows, offer them better foraging ground than orchards or groves. While the greater part of their food consists of insects that fly, a few wingless forms, as ants, spiders, and caterpillars, are taken, but these are most likely picked from the tops of weeds as the birds dart past. Some ants have wings at certain times and so become part of the usual fare. In this investigation of the martin's food, 56 stomachs were examined, taken in the five months from March to July, and the contents found to consist entirely of animal matter.

As might be expected, beetles do not occupy a high rank in the food of the martin, most of them being but little on the wing. Together they form only

1 Progne subis. 
5.14 per cent of the whole food. Less than 2 per cent are the predacious ground beetles, and less than half of 1 per cent snout beetles or weevils.

Ants (3.68 per cent) were eaten in May, June, and July. Naturally, these were the winged forms, though a few wingless ones may occasionally have been taken. Other hymenopterans, as bees and wasps, are taken much more frequently (14.67 per cent).

True bugs form the largest item of diet of the martin and consist for the most part of the larger flying species, as stinkbugs, shield bugs, and leaf-legged bugs, with some tree-hoppers. They are found in the food of every month and in all amount to 41.41 per cent. The great bulk of the bug tribe are noxious insects and include some of the worst pests of agriculture.

Flies are eaten to the extent of 7.2 per cent, and consist largely of the long-legged crane flies, or "daddy longlegs," so called. Lepidopterans are represented in the stomachs of most birds by their larvæ, commonly known as caterpillars; but the martin, taking its food on the wing, catches the adult insects, the moths, or butterflies. Most of the moths eaten, however, are very small, so that they form only 1.25 per cent of the food. Butterflies were found in only one stomach. Grasshoppers and crickets ( 3.58 per cent) are eaten principally in May and June, instead of August, which, with most birds, is the usual month for eating grasshoppers.

A somewhat peculiar article of the martin's diet is the remains of large

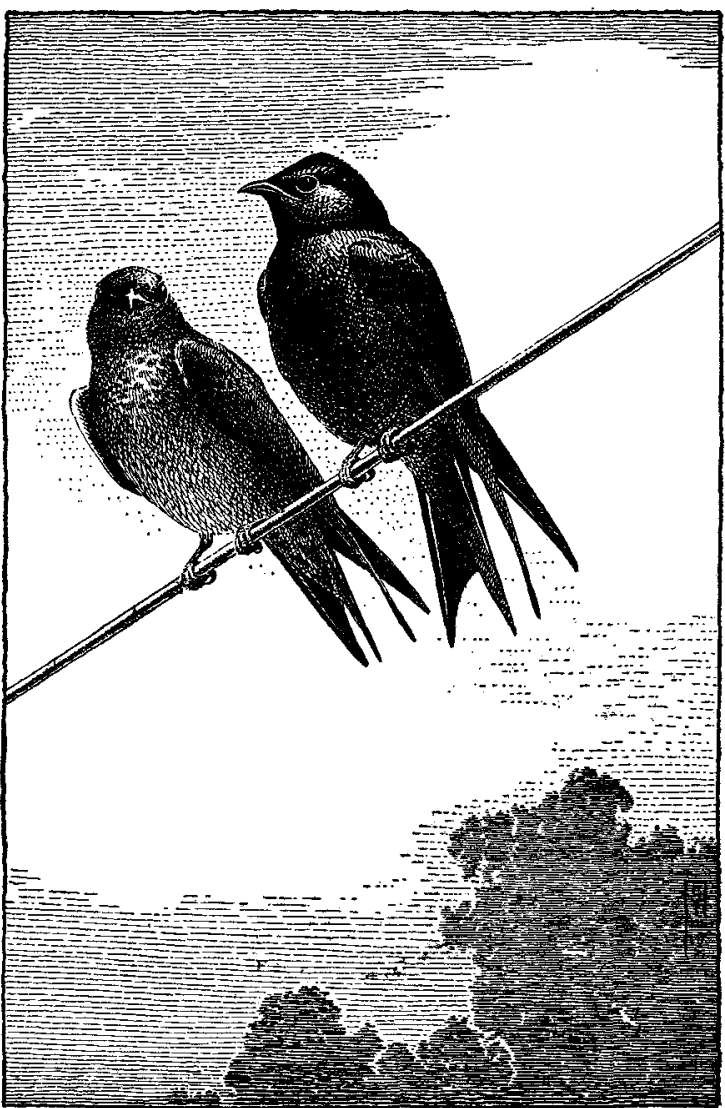

FIG. 15.-Purple martin. Length, about 8 inches dragonflies, found in 29 of the 56 stomachs examined. Six stomachs were entirely filled with these rather formidable looking creatures. As dragonflies feed upon mosquitoes and other small insects, the martin can not be considered as doing man a service by eating them. Besides insects a few spiders also were eaten.

Among the harmful insects destroyed by the martin may be mentioned the clover leaf weevil, found in a number of stomachs, one of which contained upward of 40 individuals. An engraver beetle, a form that does great damage to timber, was found in one stomach and the cotton boll weevil in another. Several stomachs contained honey bees, but all were males or drones.-F. E. L. B. 


\section{SCISSOR-TAILED FLYCATCHER ${ }^{1}$}

The scissor-tailed flycatcher (fig. 16) is found chiefly from central and eastern Texas and Oklahoma to southern Kansas during the months from April to October, and casually in western Louisiana, western Arkansas, and southwestern Missouri. It occasionally wanders to far-distant sections, and in winter moves

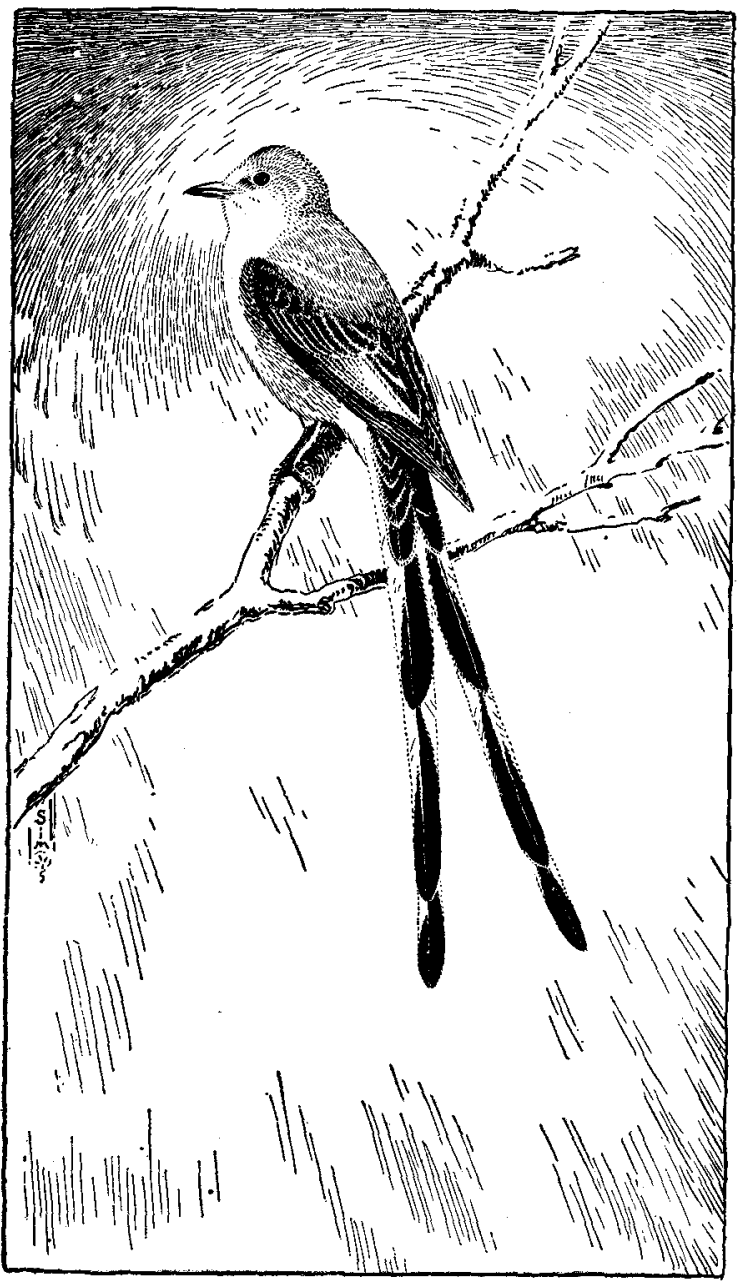

FIG. 16.-Scissor-tailed flycatcher. Length, about 14 inches farther south and with few exceptions retires beyond the southern boundary. Like the kingbird, it prefers for nesting sites open country, and it seems to be best suited with prairies or rolling land with scattered trees. In settled territory it takes kindly to orchards and even gardens in the near vicinity of buildings. While generally a quiet bird living on good terms with its neighbors, it displays some of the aggressive spirit of the kingbird as regards crows and hawks, and whenever they appear near its nest attacks them with great vigor.

The following discussion of this bird's food is based upon examination of the contents of 128 stomachs rather irregularly distributed over the seven months from April to October. All are from Texas except one from Florida, which is considerably outside of the bird's usual range. The stomach contents were divided between 96.12 per cent animal food, practically all insects and spiders, and 3.88 per cent vegetable, chiefly small fruits and seeds.

Of the animal food, beetles (13.74 per cent) form a rather constant article of diet. Less than 1 per cent belong to theoretically useful families. The others are practically all harmful. The well-known 12-spotted cucumber beetle, which is often very injurious to the cucumber, as well as to squash vines, corn, clover, beets, beans, peas, and asparagus, was found in one stomach. Snout beetles, or weevils, occurred in a number of stomachs, and the well-known cotton-boll

\footnotetext{
1 Muscivora forficata.
} 
weevil in four. Most of the beetles are consumed in May, and the least in June, but as only two stomachs were taken in the latter month the record is subject to revision.

Bees, wasps, and ants are eaten to the extent of 12.81 per cent of the yearly food, which is the lowest record but one for this item among birds of the flycatcher tribe. As a rule this kind of food constitutes one of the most important elements of the flycatcher's diet, as these insects, excepting ants, being almost constantly on the wing during daylight, are peculiarly adapted to these birds' methods of feeding. Those eaten by the scissor-tail are mostly of the larger kinds, i. e., bees and wasps, with very few of the smaller parasitic species.

Bugs (10.17 per cent of the diet) were found in 47 stomachs. At least nine families were identified, but stinkbugs were most abundant and were found in 22 of the 47 stomachs. In two stomachs was identified that disagreeable pest, the squash bug, a creature not classified by entomologists in the stinkbug family, but if disgusting odor were the chief requisite, it is well qualified for that honor. Most of the other bugs identified are harmful. Flies (3.8 per cent), found in the stomachs taken in April, May, and September only, do not seem to appeal to this flycatcher; in 8 of the 14 stomachs they were identified as robber flies.

Grasshoppers and crickets, evidently a favorite diet of the scissor-tail, were found in goodly quantity in the food of every month except April. The average for the year is 46.07 per cent-the highest for any flycatcher. The one stomach taken in October contained these insects to the extent of 86 per cent, but it is probable that the month of maximum consumption is July, when they attain 65 per cent. As this bird is said seldom to alight upon the ground, these insects must be captured during their flight or jumps. In general, grasshoppers and crickets are eaten most by ground-feeding birds, as the meadow lark, while flycatchers take bees, wasps, etc. With this bird the rule seems reversed. Of 128 stomachs, 88 contained grasshoppers or crickets and 8 held no other food.

Caterpillars, with a few moths, constitute a small but rather regular article of diet with the scissor-tail (4.61 per cent of the year), and were found in the stomachs of every month except October. The cotton-leaf worm was identified in several stomachs and the cotton bollworm in one. The latter is a well-known pest in cotton fields and also feeds upon a number of other cultivated plants, including sweet corn, from which it is known also as the corn worm. It preys also upon tomatoes and occasionally upon beans and peas. A few dragonflies, together with miscellaneous insects and spiders, complete the animal food (4.92 per cent).

The vegetable food of the scissor-tail consists of small fruit, or berries, and a few seeds. The total percentage, 3.88 , indicates that this is not the favorite, but is taken for variety.

The food of the scissor-tailed flycatcher requires but little study to show that where the bird is abundant, it is of much economic value. The bird selects a diet almost entirely of insects, but in this the useful species are so few that they may be disregarded. Its consumption of grasshoppers alone is sufficient to entitle the scissor-tail to complete protection.-F. E. L. B.

\section{RED-COCKADED WOODPECKER ${ }^{1}$}

The red-cockaded woodpecker (fig. 17) is an inhabitant of the Southeastern States from eastern Texas north to southern Virginia and southern Missouri. Pine woods are its favorite haunt, and a large percentage of its food is obtained from pine trees. No complaints have yet been heard that this bird harms crops or forest trees, nor does analysis of its food indicate that such is the case. So far as shown, it does not frequent orchards or cultivated land.

1 Dryobates borealis. 
Ninety-nine stomachs from Georgia, Alabama, Florida, Mississippi, Louisiana, and Texas, representing every month, but not many in each, were examined. of the total food, 86.08 per cent was composed of insects, and the remainder, 13.92 per cent, of vegetable matter, mostly seeds of conifers.

Useful beetles were found in nine stomachs, and amount to about 2 per cent of the whole food. Other beetles, chiefly the larva of wood-boring species, aggregate 15.65 per cent of the annual diet. Of these a number were weevils, or snout

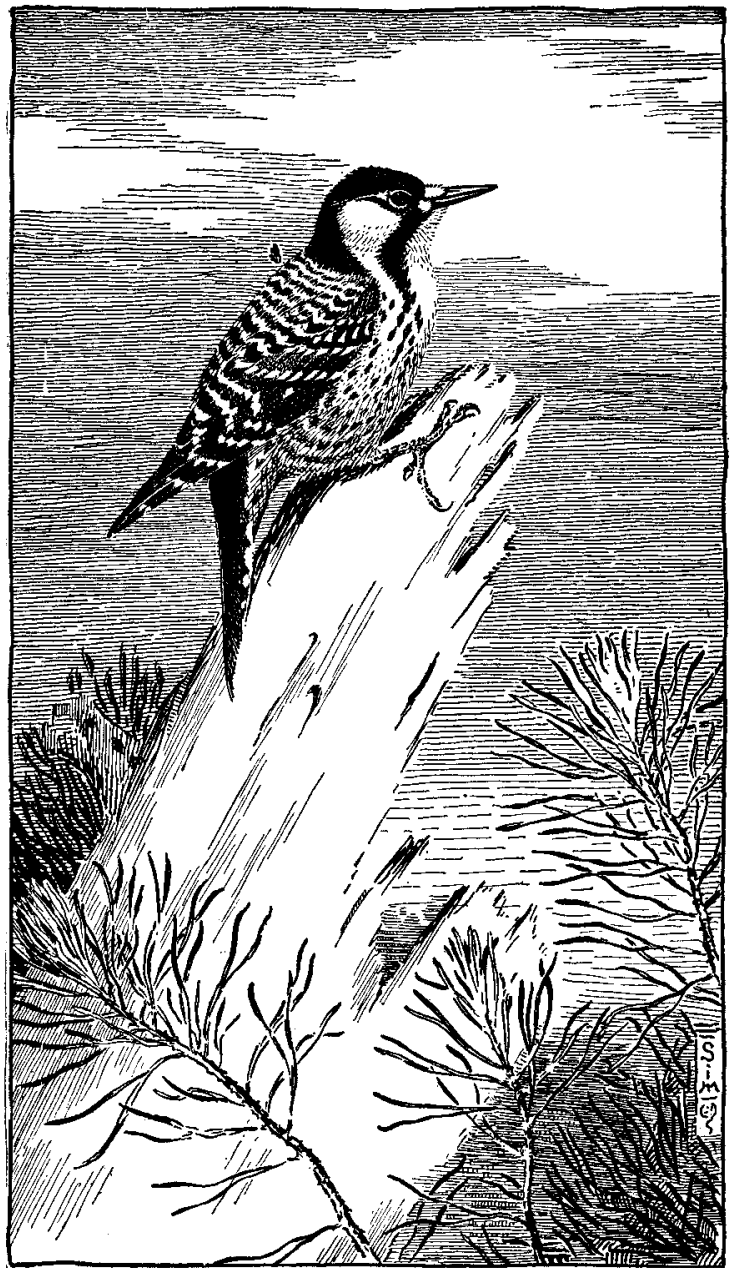

FIG. 17.-Red-cockaded woodpecker. Length, about $81 / 2$ inches beetles. Ants, evidently the favorite food, were eaten to a great extent in every month. December is apparently the month of least consumption $(28.93$ per cent), and July of maximum (69.6 per cent), but the data are hardly sufficient to give final figures. The average consumption for the year (51.72 per cent) is exceeded by few other birds.

True bugs, many of which are scales, or bark lice, are eaten to the extent of 6.99 per cent of the food. The others are mostly pentatomids, or soldier bugs. Nearly all were taken in the five months from December to April, and two-thirds of them in December and January. These insects, and especially the pentatomids, are lovers of warm weather and sunshine and many live on fruit. It seems probable that this bird gets them from their hibernating places. Grasshoppers, crickets, caterpillars, white ants, spiders, and egg cases of cockroaches, make up the rest of the animal food.

The greater part of the vegetable food, about a tenth of the total, consists of mast, mostly seeds of conifers. This was found in 45 of the 99 stomachs, and appears to be a somewhat regular article of diet, especially in the colder months. Fruit pulp, poison-ivy seeds, bayberry and other seeds, cambium, and rubbish each occurred in a few stomachs, and together amount to about 4 per cent of the food. Corn was found in four stomachs, and unidentified fruit pulp in eight. The cambium was contained in four stomachs, and the seeds of poison ivy in one. 
From the foregoing it is evident that the red-cockaded woodpecker does little if any damage to products of husbandry and that it does good work in the forest by devouring wood-boring larvae. No doubt it aids in distributing the seeds of the pines upon which it feeds, but its food has little other economic interest.F. E. L. B.

\section{CHUCK-WILL'S-WIDOW '}

The chuck-will's-widow (fig. 18), an interesting nocturnal bird, breeds throughout the area to which this bulletin is devoted. Like other species of its family, it lays only two eggs, which may be deposited almost anywhere on the forest floor, there being no nest. Intrusion on this spot usually results in the bird moving the eggs, which it carries in its mouth.

The bird's flight is noiseless and graceful, and is somewhat more extended and sustained than that of the whip-poor-will but less so than that of the nighthawk. Its call note, which has given rise to the name here used as well as to others of similar sound, is like that of the whip-poor-will, with an added syllable.

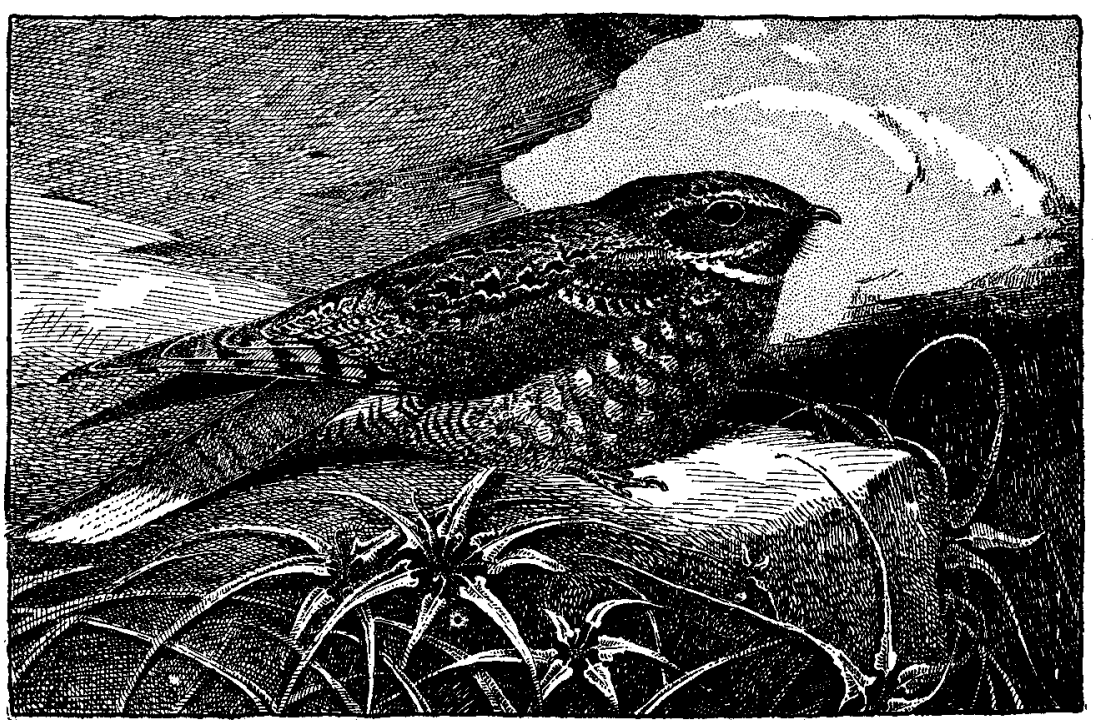

FIG. 18.-Chuck-will's-widow. Jength, about 12 inches

The color of the chuck-will's-widow is a harmonious blend of buff, brown, and black, well adapted to concealing the bird as it rests quietly in the woods by day. Surrounding the mouth are numerous branched bristles which with the enormous gape make a very efficient insect-catching apparatus. Although the bird is only 12 inches long, the mouth fully extended forms an opening at least 2 by $3 \frac{1}{2}$ inches in size. It is but natural, therefore, that the bird should prey upon some of the largest insects.

Not only are large insects captured and swallowed, but even small birds. Three of the 45 stomachs of the chuck-will's-widow thus far examined contained remains of birds, in two cases warblers. As 42 of the 45 stomachs were collected in April and May, the food percentages apply only to those two months. The percentage made up of small birds is 7.21 .

Over 58 per cent of the food is composed of large beetles of the family of leaf chafers. Considerably more than half of these are May beetles, the adults of the

1 Antrostomus carolinensis. 
white grubs so destructive to forage crops and lawns. Among other destructive beetles of this group eaten by the chuck-will's-widow are the spotted vine chafer, and several othens injurious to grapevines and apple trees. There were found also in stomachs of this bird specimens of the southern pine sawyer, a borer that in the South has destroyed timber valued at millions of dollars; beetles of a group whose larvæ bore in roots, sometimes of orchard trees; and the palmetto weevil, which is sometimes destructive to palms.

Moths, mostly of large species, compose 12.36 per cent of this bird's food in April and May, and dragonflies 4.63 per cent. Specimens were taken of the largest dragonfly known to occur in eastern United States. Other items of insect food are water beetles, ground beetles, click beetles (the adults of wireworms), crane flies (injurious to pastures), horseflies, roaches, and green locusts.

Despite the fact that the chuck-will's-widow occasionally devours smaller insectivorous birds, it must be reckoned a useful species. It is probable that birds are not deliberately sought, but that they are taken instinctively, as would be a moth or other large insect coming within reach of that capacious mouth. Generally speaking, therefore, the chuck-will's-widow is insectivorous and most of the insects it eats are destructive.-W. L. M.

\section{NIGHTHA WK ${ }^{1}$}

The nighthawk, or bull-bat, has unfortunately attracted more attention as a target for shooting practice than as an object of esthetic and economic consideration. How many thousands of these useful birds have been sacrificed in this thoughtless way it would be difficult to estimate, but the practice has been extant since early times and has resulted in an enormous reduction in their numbers. What is worse, the nighthawk is particularly unfitted to withstand this sort of persecution, as it lays only two eggs. Thus perpetuation of the species under favorable conditions is only barely assured. The bird deserves very different treatment. As an adornment of the landscape it has few superiors among birds (see illustration on title-page). A flock of nighthawks pursuing their complex but skillful aerial evolutions is an object of interest and admiration seldom excelled. Not only has the species a pronounced esthetic value, but economically it is practically beyond reproach. The nighthawk is strictly insectivorous, and for this reason no blame can be attached to it on the score of its damaging crops. The only charge that can be made against the bird is that it destroys some useful insects, but these are far in the minority.

Nighthawks are so expert in flight that no insects can escape them. They sweep up in their eapacious mouths everything from the largest moths and dragonflies to the tiniest ants and gnats, and in this way sometimes gather most remarkable collections of insects. Several stomachs have contained 50 or more different kinds, and the number of individuals may run into the thousands.

Nearly a fourth of the bird's total food is composed of ants. These insects are generally annoying and often very injurious, especially in relation to stored products and in their activities in fostering destructive plant lice. More than a fifth of the nighthawk's food consists of May beetles, dung beetles, and other beetles of the leaf chafer family. These are the adults of white grubs, noted pests, and even as adults many members of the family are decidedly harmful.

Numerous other injurious beetles, as click beetles, wood borers, and weevils, are eaten: True bugs, moths, flies, grasshoppers, and crickets also are important elements of the food, as are several species of mosquitoes, including the transmitters of malaria. Other well-known pests consumed are the Colorado potato beetle, cucumber beetles, rice, clover leaf, and cotton-boll weevils, billbugs, bark

1 Chordeiles virginianus. 
beetles, squash bugs, and moths of the cotton worm. No fewer than 18 speeies of bark beetles, which are among the most destructive forest enemies, have been identified in the food of the nighthawk.

Nighthawks deservedly receive full legal protection everywhere, and citizens should see that the law is obeyed. The nighthawk is far too useful and attractive a species to be persecuted. Especial attention should be given to safeguarding any eggs that may be found. They are deposited on the bare ground or rocks, on logs, or on flat gravel roofs in cities.-W. L. M.

\section{YELLOW-BILLED CUCKOO ${ }^{1}$}

Cuckoos are rather shy birds, keeping among the foliage of trees or bushes and making but little noise. They do not, however, entirely avoid the abodes of man, but where trees are abundant many may frequently be seen about houses or even in the village streets or parks. On very hot mornings in midsummer their familiar though not very musical cry of "kow-kow" is said to presage rain; hence the name "rain crow" by which these birds are frequently known.

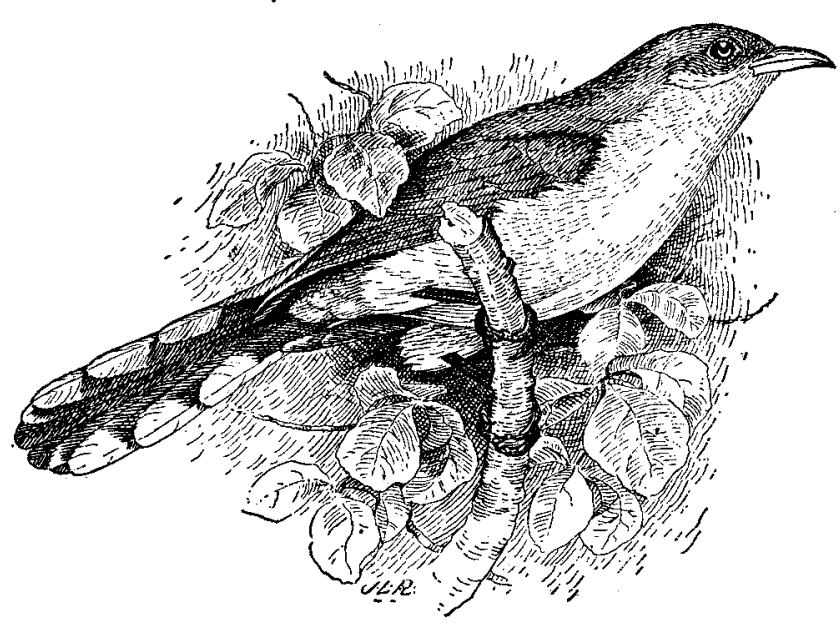

FIG. 19.-Yellow-billed cuckoo. Length, about $121 / 4$ inches

The two most abundant species in the United States are the black-billed and yellow-billed cuckoos, but the yellow-bill (fig. 19) is more abundant and better known in the South and probably is the more important economically.

The common observation that cuckoos feed largely on caterpillars has been confirmed by stomach examination. Furthermore, they appear to prefer the hairy and spiny species, which are supposed to be protected from the attacks of birds. The extent to which cuckoos eat hairy caterpillars is shown by the inner coatings of the stomachs, which frequently are so pierced by these hairs and spines that they are completely furred.

For this treatise 110 stomachs of the yellow-billed cuckoo were available, all but one taken from April to October. That one, secured in Texas in January, was of a bird which had remained in the United States after its companions had moved on farther south; its food consisted of one large harvest fly or "locust" and two or three spiders, the latter very unusual food at this season.

The contents of the other stomachs were practically all animal matter, only a small fraction of 1 per cent of vegetable rubbish being found in one stomash

\footnotetext{
1 Coccyzus americanus.
} 
taken in Texas in August and one seed of sour gum in a stomach taken in Alabama in October. Over $\$ 2$ per cent of the food consists of three orders of insects, viz, bugs (12.25 per cent), caterpillars (65.63 per cent), and grasshoppers (14.34 per cent).

Bugs found in 37 stomachs were nearly all of the larger kinds, like cicadas, stinkbugs, squash bugs, and leaf-footed bugs. They constitute an important article of food from April to August, after which they disappear. July is the month of greatest consumption (29 per cent), and the average for the four months from April to July is more than a fifth of the whole food (21.98 per cent). Among the bugs were the periodical cicadas and several forms injurious to oranges and melons and other cucurbit crops.

Caterpillars were found in 91 stomachs and in 24 they were the sole contents. One of the most important of these is the cotton worm, found in 34 stomachs in numbers varying from 1 to 150 each. At least four held 100 each, and it is probable that the average number of these insects in the 34 stomachs was 50 . It is hardly necessary to comment upon the economic importance of this work. Until the introduction of the cotton-boll weevil, the cotton worm was the worst pest with which the southern planter had to contend. In the southern tier of cotton States a loss of a fourth of the crop was formerly expected, and if the yield was not reduced a half the planter considered himself fortunate. Examination of many stomachs shows that this insect is a common article of daily food for the cuckoo, as well as for many other birds, and that these birds must exercise a very important restraint upon its increase.

The apple-tree tent caterpillar was found in one stomach. Where apples are grown this insect is a pest, and it is fortunate that there is a bird ready and willing to restrain its ravages. Another caterpillar eaten by the cuckoo was the redhumped apple caterpillar, an insect that feeds in colonies upon apple and other trees and often does considerable damage. In all, caterpillars constitute twothirds of the total food of the yellow-billed cuckoo in the South. Few birds feed so exclusively upon any one order of insects.

The natural food for cuckoos would seem to be bugs and caterpillars which feed upon leaves, as these birds live in the shade among the leaves of trees and bushes. Not so with grasshoppers, whose favorite haunts are on the ground in the blazing sunshine, yet these creatures are the second largest item in the cuckoo's diet. Grasshoppers are so agreeable an article of food that many a bird apparently forsakes its usual feeding grounds and takes to the earth for them. Thus it is with the cuckoos; they quit their cool, shady retreats in order to gratify their taste for these insects of the hot sunshine. But there are some members of the grasshopper order that live in the shade, as katydids, tree crickets, and ground crickets, and these are all used to vary the cuckoo's bill of fare. Grasshoppers, crickets, and katydids as a whole constitute 14.34 per cent of the cuckoo's diet.

Beetles (3.16 per cent), eaten so extensively by so many birds, are of minor importance in the diet of the cuckoo. Only a trace of the predacious ground beetles was found. The others were divided into small portions among several families, and no special pest among them was noted. Ants, wasps, and bees comprise less than 1 per cent and are evidently not favorites. A few spiders are taken, mostly in June, and a few moths also are eaten, but the most unexpected food for the cuckoo was three small tree frogs, found in as many stomachs.

As the birds discussed in this paper were colleeted from a limited area, it will be of interest to take a glimpse at some facts obtained by the examination of stomachs of the same species taken in all parts of the United States. Of a total of about 300 stomachs, the Colorado potato beetle was found in 4 ; the dog-day harvest fly, or "loc'1st," in 33; the cotton worm in 37 , many stomachs containing over 100 individuals; the yellow-necked apple caterpillar in 34, many stomachs 
completely filled with them; the fall webworm in 3 , one of which held 250; and the tent caterpillar in 7 stomachs, frequently to the extent of 100 or more individuals each. In all of these cases the statements are very conservative, as these larvæ are so soft that they soon become unrecognizable in the process of digestion, and only those recently eaten can be identified.

The yellow-billed cuckoo is a valuable ally of the farmer. It has no objectionable habits, but does destroy many serious agricultural pests, chief among which are the many species of caterpillars, of which this bird makes about two-thirds of its food.--F. E. L. B.

\section{BOBWHITE}

No bird is better known to country residents than the bobwhite (fig. 20). The bird's cheery calls the year round form part of the most pleasant associations of country life, and its neat form and harmonious coloration, and especially its confiding habits, make it a general favorite.

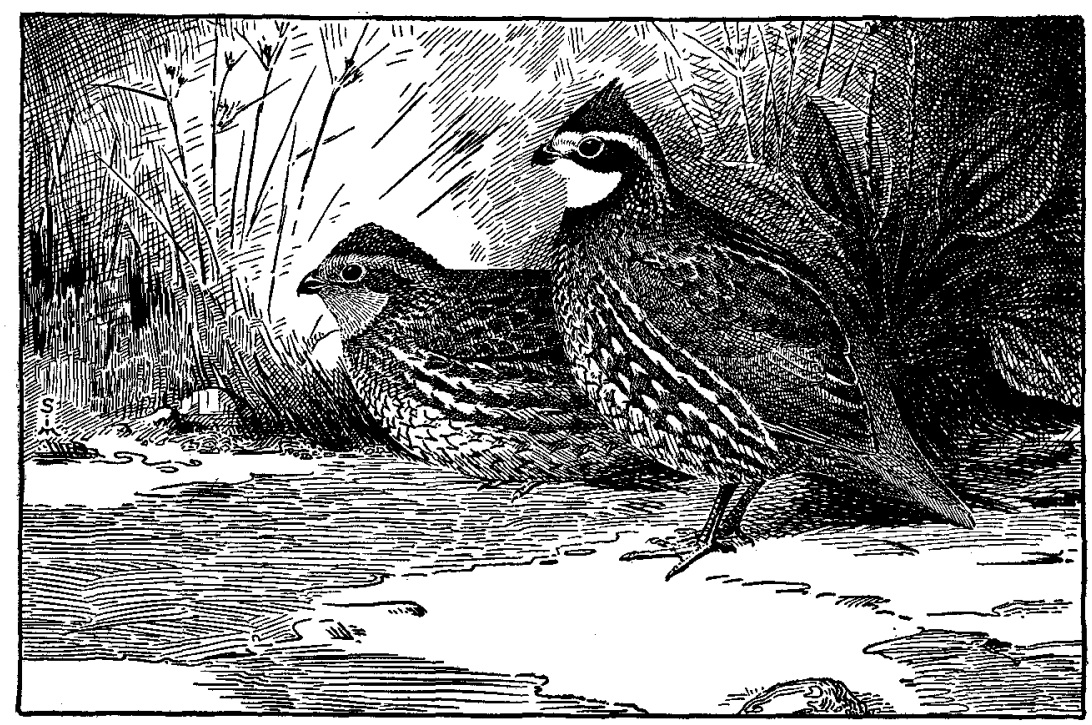

Frg. 20.-Bobwhite. Length, about 10 inches

Any brushy fence row serves as a retreat for its nest, or for winter shelter, and weed-covered fields are its favorite feeding places. Weed seeds form more than half the total food and include those of all the worst weed pests of the farm. Among them may be mentioned crab, cockspur, witch, and foxtail grasses, sheep sorrel, smartweed, bindweed, lamb's-quarters, pigweed, corn cockle, chickweed, charlock, partridge pea, beggar lice, nail grass, rib grass, ragweed, and Spanish needles.

Acorns, beechnuts, chestnuts, and pine seeds make up about 2.5 per cent of the food, and wild fruits about 10 per cent. The fruits include berries of palmetto, smilax, wax myrtle, mulberry, sassafras, blackberries and raspberries, rose haws, cherry, sumac, grapes, sour gum, blueberries, honeysuckle, partridge berry, and a number of others. The bobwhite feeds to a slight extent upon buds and leaves, including those of yellow and red sorrel, cinquefoil, and clover.

1 Colinus virginianus. 
Grain forms scarcely more than a sixth of the food, but most of it is taken during winter and early spring when nothing but waste grain is available. The habit of gleaning this after the harvest is beneficial to the farm, for volunteer grain is not desirable, especially where it serves to maintain certain insect and fungus pests. Although most of the grain and seed crops grown upon the farm are represented in bobwhite's dietary, no significant damage can be attributed to the bird.

Animal food, chiefly insects, composes nearly a sixth of the bird's subsistence. From June to August, inclusive, when insects are most numerous, their proportion in the food is about 36 per cent. The variety of insect food is great and includes a number of the most destructive agricultural pests. Among them may be mentioned the Colorado potato beetle, 12-spotted cucumber beetle, bean leaf beetle, squash ladybird, wireworms, May beetles, corn billbugs, clover leaf weevil, cotton boll weevil, army worm, bollworm, cutworms, and chinch bug.

On the strength of the bobwhite's feeding on the boll weevil, a campaign has been waged in several Southern States for complete protection for the bird. This movement is particularly ill advised, since this bird is by no means prominent among the enemies of the boll weevil. Some 220 stomachs of bobwhites collected in cotton fields have been examined, with the result that a single boll weevil was found in each of two stomachs. Reports that bobwhites eat large numbers of boll weevils are based on field observations, which are very liable to inaccuracy, and upon the behavior of captive birds, which has little if any value as an indication of their habits under natural conditions.

On the other hand, the food habits of the bobwhite undoubtedly are beneficial and the bird should be maintained in numbers on every farm. This is not to say that all shooting should be prohibited, for the bird is very prolific. But its numbers should not be reduced below what the available nesting sites and range will support.-w. L. M.

\section{BARN OWL ${ }^{1}$}

The barn owl (fig. 21) is a peculiar-looking bird, differing considerably from our other owls. The legs are long and slender and the general color is yellowish buff, with small black markings. The face is triangular in outline and appears more like a caricature of a near-human face than do those of other owls; this is the reason for the name monkey-faced owl. The odd appearance of the bird, together with its usual seclusive habits, gives occasional captures an undue importance in the popular mind, it being usually thought that some great rarity has been captured. The bird is fairly numerous, however, and very widely distributed, being practically cosmopolitan. Its notes include a thrilling scream, various scraping and creaking notes, and hisses.

The barn owl's natural nesting sites include cavities in trees, banks, or cliffs, but the birds frequently occupy the attics of deserted buildings, towers, steeples, and the like. The nest itself often consists only of relics of pellets of bones and hair, disgorged by the parent-birds. However that may be, the presence of this material about the nest renders it easy to make a study of the food of the barn owl. So far such study has resulted uniformly in favor of the bird.

For years barn owls have nested in one of the towers of the Smithsonian Institution, in Washington. Hundreds of pellets have been collected there and examined to determine the number and kinds of animals represented in them. This is a comparatively easy task, since the skulls of the animals eaten usually are intact. In one lot of 675 pellets collected at this place there were found a total of 1,587 small mammals, of which 1,119 were meadow mice, 452 house mice, and 134 common rats.

\footnotetext{
1 Tyto alba pratincola.
} 
The barn owl takes only a small proportion of birds or other useful animals and consequently is of great value to agriculture. In the Western States it not only feeds upon the destructive rodents mentioned above, but also upon pocket gophers, which individually are even more injurious.

I 1 i should be borne in mind also that the barn owl is by no means the only beneficial species of its kind, for with the exception of the great horned owl, all of our owls are much more useful than injurious. They deserve almost complete protection rather than the persecution to which they are customarily subjected.-W. L. M.

\section{TURKEY BUZZARD ${ }^{1}$}

Turkey buzzards (fig. 22) are familiar features of southern landscapes. On the ground they appear uncouth and awkward, but in the air show a skill, particularly in soaring, approached by few other birds.' Their wonderful soaring flight has been a subject of study by a multitude of observers, and the buzzard is not only the model but also the inspiration of the American invented airplane. The bird is chiefly black in color, but the naked skin of the head and neck and the base of the bill are bright red.2

Buzzards nest on the ground under brush piles, bushes, or palmettos, or in hollow logs or rock

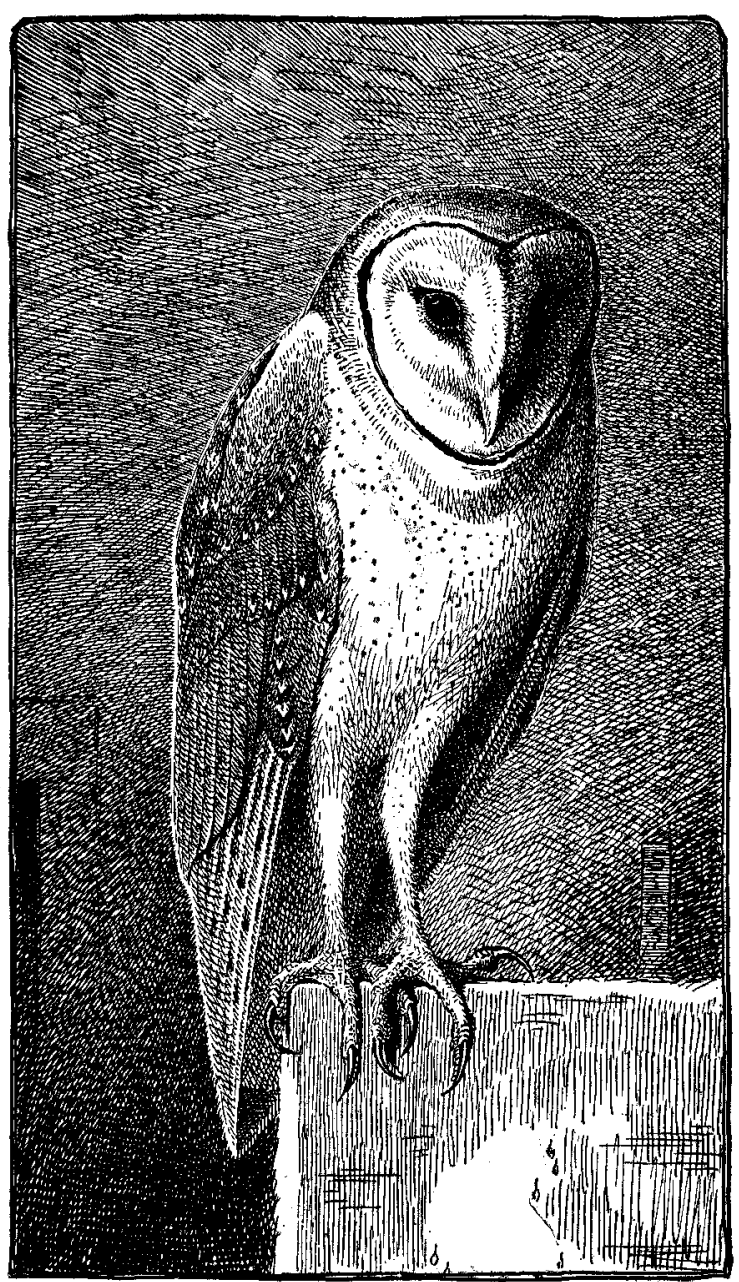

FIG. 21.-Barn owl. Length, about 18 inches crevices. They roost usually on dead branches, and sometimes, especially in winter, congregate in large numbers.

All vultures specialize in feeding on carrion. While under natural conditions the number of dead animals available for them is somewhat limited, yet, where

1 Cathartes aura septentrionalis.

2 The black vulture (Coragyps atratus), more abundant near the seacoast and more southern in distribution than the turkey buzzard, differs from the latter in having the head and neck black, and the under surface of the wings silvery. The flight of this vulture is more labored, and accompanied by more flapping of the wings. In general habits the two birds are alike. 
the human population is considerable and sanitary conditions not over good, there is much work for buzzards, and they fill an important place. For nearly three centuries their work has been appreciated at its full value in the South, and these birds have been scrupulously protected.

The turkey buzzard now is threatened with persecution in the land where heretofore it has received the most zealous protection, for the bird has been

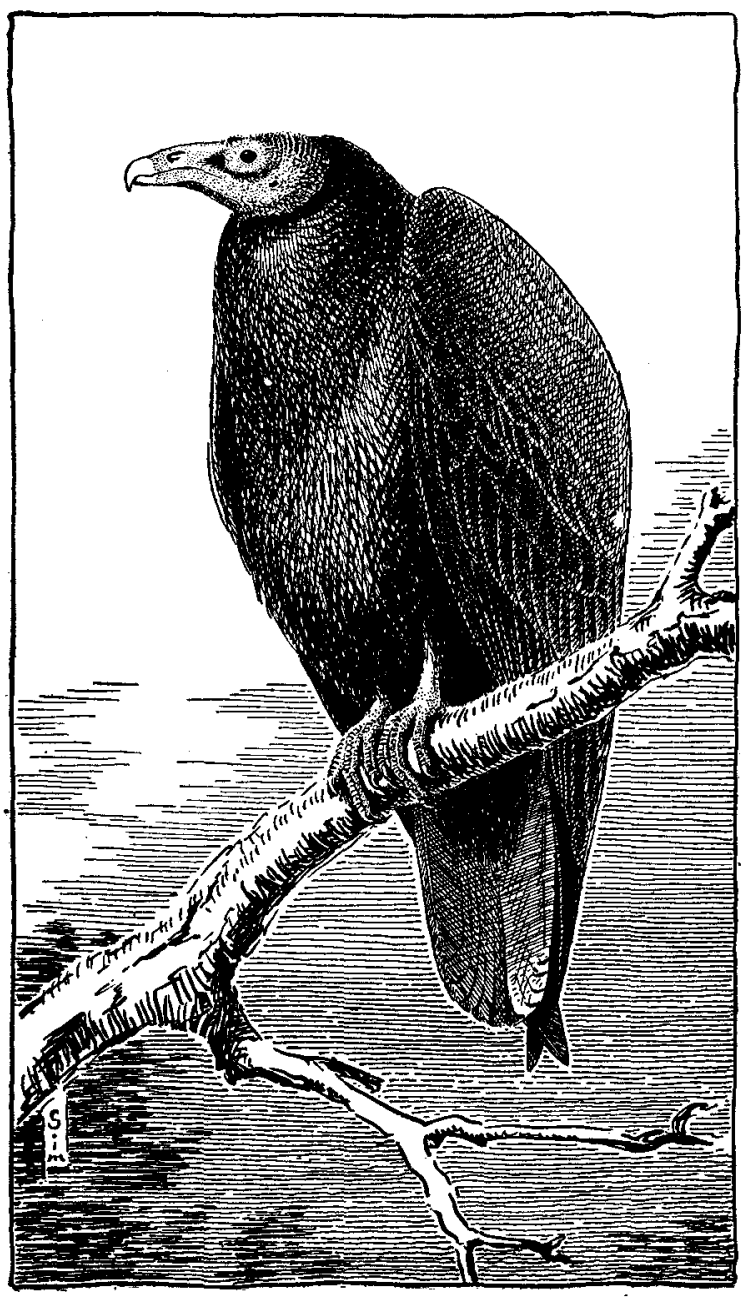

FTo. 22.-Turkey buzzard. Length, about 30 inches accused of spreading such diseases of livestock as hog cholera and anthrax. The charge that it spreads hog cholera has never been demonstrated, and until this is done judgment should be suspended. Its relation to anthrax has been investigated, with the result that in the distribution of the disease the bird must be considered a minor agency as compared with man and various domestic and certain wild animals.

The nature of their food would indicate that buzzards have strong digestive powers. The spores of anthrax, or charbon, a virulent stock disease, have been shown by two independent investigations to be destroyed by passing through the alimentary canals of buzzards. Anthrax spores are not destroyed in the digestive tracts of other carrionfeeding animals, as the dog, cat, hog, chicken, or opossum. It has also been shown "that the virus of hog cholera is digested in the intestinal

tract of buzzards, and that the droppings of buzzards fed on the flesh of hogs dead from cholera do not produce cholera, when mixed in the feed of hogs." 1

It is true that buzzards may carry the germs of anthrax or other stock diseases on their plumage, feet, or bills, and thus distribute them; but all the other animals just mentioned may similarly carry disease germs on the surface of their bodies, as may also flies, domestic pigeons and other poultry, horses, mules, and

1 Twenty-sixth Annual Report, State Board of Health of Florida, p. 204, 1914. 
cattle, not to mention members of the human family. In fact, at the same time that steps are being taken greatly to reduce or exterminate a wild bird-the buzzard-which may possibly play a minor part in the transmission of anthrax, farmers are harboring several domestic animals that have far greater possibilities as spreaders of the disease. The fact that anthrax may be carried by flies is more than sufficient to explain the most severe epidemics.

Obviously, it is unfair to attempt to place the blame for general dissemination of stock diseases on the buzzard. Considering the multitude of ways in which these diseases may be spread, it can not be doubted that stock diseases would be as widely distributed as now if turkey buzzards were eliminated, as has been proposed. What amounts to proof of this is the fact that hog cholera at times is virulent and seriously destructive in regions where there are few or no turkey buzzards, as in certain Northern States and Canadian Provinces.

Attacks in the South by buzzards upon living farm animals indicate that there are too many buzzards there for the best economic interests. In the North, where buzzards are fewer, such attacks are believed never to occur. Reduction in the number of buzzards may be desirable, especially if accompanied by or resulting from a proper system of carrion disposal, but there is a wide gulf both in meaning and desirability between reduction in numbers and extermination.

A frequently suggested method for conducting a destructive campaign against the buzzard is by shooting. Inevitably, however, the guns would largely be in the hands of the less responsible classes of the population, and many birds other than buzzards would undoubtedly be shot. This is a forceful argument against undertaking extermination of buzzards unless definitely proved to be necessary.-W. L. M. 